\title{
Field Training Monitoring of Alpine Ski Athletes Using a Triaxial Accelerometers
}

\author{
Jin Su Suk', SeoungKi Kang ${ }^{1 *}$, Jae Hyung Lee ${ }^{1}$ and Young Ha $\mathrm{Ji}^{2}$ \\ ${ }^{1}$ Yongin University \\ ${ }^{2}$ Korea Ski Association
}

Article Info

Received 2021.10.31.

Revised 2021.12.22.

Accepted 2021.12.24.

Correspondence*

SeoungKi Kang

ksk0527@hanmail.net

Key Words

Alpine ski,

Triaxial accelerometers,

Training monitoring

PURPOSE This study was designed to propose a quantitative base training evaluation method through alpine ski training monitoring using a triaxial accelerometer. METHODS Twelve Korean alpine ski athletes, six each in France and New Zealand, participated in this study. Activity data during training and daily living were collected for 7 days via the Actigraph GT9X. The collected data were downloaded through ActiLife Ver 6.13.1. Energy expenditure was calculated with Freedson (2011), and the resting metabolic rate was corrected using the Harris \& Benedict (1918) formula. Further, the physical activity intensity classification criteria and METs formula of Freedson (1998) were used to classify hourly activity intensity. The collected data were organized by date, time, intensity, and energy expenditure using Microsoft Excel 2016. Differences between weekdays vs. weekends and skiing vs. physical training were analyzed through a paired sample t-test using Windows SPSS 23 with a significance level of $a=.05$. RESULTS First, both groups showed repetitive on and off high-intensity activities during scheduled ski training and competition. Second, moderate-intensity activities accounted for an average of $6-10 \%$, and the weekly total time and intensity of MVPA was very high. Finally, the group from France showed differences in total energy expenditure during weekdays vs. weekends $(p<.05)$ and the energy expenditure of both ski training and physical training during weekdays vs. weekends $(p<.05)$. The New Zealand group showed a difference in total energy consumption during weekdays vs. weekends ( $p<.05$ ). CONCLUSIONS A systematic training program based on quantitative training evaluation should be developed for alpine ski athletes to maintain proper rest and exercise intensity levels.

\section{서론}

동계 올림픽 설상 종목은 알파인(alpine), 노르딕(nordic), 프리스타일 스키(freestyle), 스노우보드(snowboard) 등이 있으며 이중 알파인 스 키는 대표적인 설상 종목으로 슬로프를 내려가며 설치된 기문(gate)을 통과하는 시간으로 순위를 결정하는 기록경기이다. 세부 종목은 활강 (Downhill: DH), 슈퍼대회전(Super Giant Slalom: SG)의 속도(speed) 종목과 대회전(Giant Slalom: GS), 회전(Slalom: SL)의 기술(technique) 종목으로 구분된다. 모든 종목은 각각의 특성에 맞는 슬로프 규격과 기 문 수가 정해져 있고 경기가 실시되는 슬로프의 표고차, 길이 등 경기 장 특성을 고려하여 기문의 수를 규정 내에서 조절하여 설치할 수 있

(cc) This is an open-access article distributed under the terms of the Creative Commons Attribution Non-Commercial License (http://creativecommons.org/ licenses/by-nc/4.0/), which permits unrestricted non-commercial use, distribution, and reproduction in any medium, provided the original work is properly cited.
도록 하고 있으며 경기 운영 방식은 대회에 따라 개인전과 복합(super combine), 혼성 단체전(national team event)으로 실시되고 있다(Alejo et al., 2021; Ferguson, 2010; FIS, 2021a; KSA, 2021; Polat, 2016).

동계 올림픽을 포함한 모든 스키 국제 대회는 '국제 스키 연맹 FIS(Fédération Internationale de Ski)'에서 담당하고 있으며 알파인 스키의 국제 대회 시즌은 해당년도 7 월 또는 8 월부터 다음해 4 월까지 진행된다(FIS, 2021b). 동계종목이라는 계절적 특성에 의해 7월 겨울 이 시작되는 칠레, 아르헨티나, 뉴질랜드 등의 남반구 국가에서 시작 해 계절 변화에 따라 아시아, 아메리카, 오세아니아, 유럽의 여러 나라 를 이동하며 개최된다(Dzimbva \& Kirkova, 2020; FIS, 2021b). 이로 인해 우리나라를 포함해 대부분의 스키선수들은 동계 설상 종목이라 는 특성에 맞추어 훈련 주기와 대회 일정에 따라 적절한 국가로 이동 하여 훈련 및 시합에 참여하고 있다(KSA, 2021).

스포츠에서 우수한 경기력을 보이기 위해서는 각 종목 특성에 맞는 체력요소의 발달과 운동 기술의 향상이 종합적으로 작용한다. 이러한 
요인들은 훈련 내용과 강도의 설정에 복합적으로 영향을 미치는 요인 으로 체계적인 훈련을 계획하고 실행할 때 종목의 특성에 맞는 체력과 기술향상을 함께 고려하여야 하며(Lukàšek \& Vychodilovà, 2016), 훈련 주기에 따라 훈련목표를 설정하고 이를 달성하기 위한 내용으로 구성되어야 한다(Silva, et al., 2017). 효과적인 훈련계획을 위해서는 현재 훈련에 대한 다양한 정보를 수집할 필요성이 있어 훈련일지 작 성과 주기적인 체력측정, 지도자의 주관적 관찰에 의한 훈련 평가방 법 등이 주로 활용되어왔다. 하지만 이러한 방법은 훈련 시간, 체력수 준의 변화 외에는 훈련 내용과 진행에 대한 정성적 자료만을 제공하 는 제한점으로 인해 이를 극복할 수 있는 체계적 훈련 모니터링은 선 수와 지도자에게 지속적인 관심의 대상이 되어 왔다(Lukàšek, et al., 2016). 왜냐하면 정확한 활동 모니터링은 훈련의 효과에 대한 정보뿐 아니라 체계적인 자료 정리를 통해 다음 훈련을 위한 정량적, 객관적 인 기초정보를 제공할 수 있기 때문이다(Neville, et al., 2010). 이러 한 현장의 요구와 관심에 따라 다양한 측정 장비를 활용한 훈련 모니 터링 연구가 현장에서 실시되고 있다(Woods, et al., 2017).

스키의 경우에도 GPS(Global Positioning System: 범지구위치결 정시스템) (Neville, et al., 2010), GNSS(Global Navigation Satellite System: 위성항법시스템) (Alejo, et al., 2021) 등의 위치기반 측정 장 비가 훈련 중 나타나는 선수의 위치변화와 이동 거리, 회전·대회전·슈 퍼대회전의 알파인 스키 세부 종목별 운동 특성을 확인하는데 활용 되 고 있으며, 무선심박수계와 간접열량계(Stöggle, et al., 2016)를 이용 하여 운동 시 나타나는 신체적 변화와 종목별 활동 특성을 분석하는 연구들이 이루어지고 있다.

하지만 이러한 연구는 종목별로 훈련을 하는 시간에 발생하는 운동 특성이나 신체적 변화만을 측정한 연구로 전체 훈련일정 동안 나타나 는 종합적인 활동 자료를 수집하지 못하는 제한점이 있다. 훈련 내용 과 방법, 그에 따른 활동 강도와 에너지소비는 선수들의 신체적 향상 뿐 아니라 균형 있는 식이 섭취 계획을 위한 기초자료로 활용될 수 있 으며 부상 예방 및 재활을 위한 적절한 운동 강도 설정 기준을 마련하 는 등 훈련 상황에 이득을 줄 수 있기 때문이다(Neville, et al., 2010; Silva, et al., 2017). 이러한 필요성에 의해서 훈련 현장에서 나타나는 활동의 빈도·강도·에너지소비량 등 객관적이고 정확한 활동 정보를 수 집하기 위하여 이중표집물(Double Labelled Water: DLW), 이동식 간접열량계 등의 측정 도구들이 사용(Crouter, Churilla \& Bassett, 2006; Troiano, et al., 2014) 되었으나 상대적으로 높은 측정비용과 장비의 착용 시 활동에 주는 제약이 많아 최근에는 가속도계를 기반으 로 한 측정 도구들이 활용되고 있다(Neville, et al., 2010).

가속도계 기반 신체활동 모니터는 작은 크기에도 불구하고 저장용량 의 확대와 길어진 배터리 수명 등의 기술적 발전으로 인해 상대적으로 저렴한 비용으로 장기적인 신체활동 정보를 수집할 수 있어 다양한 대 상의 신체활동 모니터링과 종단적 연구(cohort study)에 적용되고 있다 (Troiano, et al., 2014). 가속도계를 이용한 신체활동의 측정은 활동의 강도·빈도와 시간 그리고 측정 기간 중 나타나는 에너지소비에 대한 실 시간 정보를 대상자 개별적으로 수집할 수 있는 장점이 있으며(Crouter, et al., 2006; Leinonen, et al., 2017; Shiroma, et al., 2016) 신체 착용 시 활동에 주는 부담이 적어 운동선수들의 훈련과 시합동안 나타 나는 여러 가지 활동 특성을 정량적으로 측정할 수 있는 대안으로 활용 할 수 있다(Alejo et al., 2021; Mcnally, 2017; Neville, et al., 2010).

이러한 장점에 의해 가속도계를 이용한 훈련의 모니터링은 다양한 연 령대와 종목에서 이루어지고 있다. 축구, 야구 선수들의 훈련 중 신체활
동 차이(Leek, et al., 2011), Flag Football에서 활동 내용에 따른 중강도 이상 신체활동(Moderate Vigorous Physical Activity: MVPA) 특성 분 석(Schlechter, et al., 2018), 축구선수들의 연습경기와 실제 경기 중 나 타나는 MVPA와 에너지소비량의 차이를 확인(Mcnally, 2017)하는 연구 에서 유소년들을 대상으로 1축 가속도계 GT1M을 활용한 연구가 이루어 졌다. 또한 Lukàšek 등(2016)은 삼축가속도계를 활용하여 축구, 가라데, 투포환, 크로스컨트리 스키, 스키프(Skiff), 스키점프 등 종목별 훈련에서 나타나는 기술, 신체적 특성을 분석하였고, 폴란드 엘리트 선수들의 종 목별 훈련 중 나타나는 일일 신체활동 특성을 분석(Frączek, Grzelak \& Klimek, 2019)하기 위해 3축 가속도계 GT3X가 사용되었다.

알파인 스키는 대표적 동계스포츠로 낮은 온도와 높은 고도에서 훈 련과 시합이 이루어지는(Dzimbova et al., 2020; Polat, 2016) 특성 으로 인해 호흡을 기반으로 선수들의 활동 강도 및 에너지 소비를 측 정하는 간접열량계 사용에 어려움이 있으며(Polat, 2016), 지나치게 크고 무거운 측정 장비의 착용은 스키를 타는데 영향을 미칠 수 있어 훈련 강도와 에너지소비량 등의 정량적 자료 수집에 대한 현장의 요구 가 있음에도 불구하고 다양한 스키선수들의 활동 정보를 수집하는데 제한점이 있다. 보다 효과적인 훈련계획을 위해 이러한 제한점을 극복 하고 스키훈련 시간 외에 체력훈련과 일상생활을 포함하는 장기적 자 료를 수집하고 분석할 필요성이 있다. 이러한 맥락에서 본 연구에서는 스포츠 현장의 훈련 및 시합 중에 나타나는 활동 특성에 대한 자료를 효과적이고 장기적으로 수집하기 위해 사용되고 있는 삼축가속도계 를 사용한 훈련 모니터링을 현장에 적용하고자 한다. 따라서 본 연구 의 목적은 삼축가속도계를 이용한 알파인 스키 전지훈련의 모니터링 을 통해 훈련 기간 동안의 다양한 활동 특성을 분석하여 체계적인 훈 련계획을 위한 기초자료를 마련하고, 이를 통해 정량적 자료를 기반의 훈련 평가 방법을 제안하고자 한다.

\section{연구 방법}

\section{연구대상}

본 연구의 대상자는 알파인 스키 기술 종목 선수로 전지훈련 실시 전 지도자와 선수들에게 연구의 목적과 절차에 대한 설명을 진행한 후 자발적인 참가 의사를 밝힌 대상자를 최종 연구 대상자로 선정하였다. 연구에 참가한 인원은 총 12 명(남자 8 명, 여자 4 명)의 우리나라 알파인 스키선수로 전지훈련 지역에 따라 프랑스 6명(남자 4명, 여자 2명), 뉴질랜드 6명(남자 4명, 여자 2명)이 연구에 참여하였다. 연구대상자의 특성은 〈Table 1〉과 같다.

Table 1. Characteristic participants

\begin{tabular}{cccc}
\hline \multicolumn{2}{c}{ Variables } & $M$ & $S D$ \\
\hline \multirow{2}{*}{$\begin{array}{c}\text { France group } \\
(\mathrm{n}=6)\end{array}$} & Age (year) & 21.60 & 1.34 \\
\cline { 2 - 4 } & Height $(\mathrm{cm})$ & 173.20 & 9.54 \\
\cline { 2 - 4 } & Weight $(\mathrm{kg})$ & 70.40 & 14.74 \\
\hline \multirow{3}{*}{$\begin{array}{c}\text { New Zealand group } \\
(\mathrm{n}=6)\end{array}$} & Age (year) & 23.00 & 2.92 \\
\cline { 2 - 4 } & Height $(\mathrm{cm})$ & 172.54 & 6.02 \\
\cline { 2 - 4 } & Weight $(\mathrm{kg})$ & 72.00 & 9.46 \\
\hline
\end{tabular}




\section{측정도구}

\section{Actigraph GT9X}

본 연구에서 사용한 삼축가속도계 Actigraph GT9X(Actigraph Inc., Pensacola, Florida, USA)는 연구용으로 널리 활용되고 있는 Actigraph GT3X에 LED 화면과 다른 기기와의 호환성을 높이기 위해 Bluetooth ${ }^{\circledR}$ 기능을 추가한 모델로 크기는 $3.5 \times 3.5 \times 1 \mathrm{~cm}$, 무게 14 $\mathrm{g}$ 의 신체활동 측정 장비이다. 1 회 충전으로 최대 14 일의 신체활동 정보를 수집할 수 있으며, 총 180 일( $4 \mathrm{~GB})$ 의 정보를 저장할 수 있다. 착용 위치는 측정 목적에 따라 손목, 허리, 발목, 허벅지 중 선택할 수 있으며 손목시계 밴드, 허리 착용 클립(clip), 탄성 밴드(elastic band)를 이용하여 적절한 신체 부위에 착용할 수 있다(Actigraph, 2021a). GT9X에서 수집되는 신체활동 정보는 X, Y, Z축으로 구분되며 축별 정보는 $V M=\sqrt{X^{2}+Y^{2}+Z^{2}}$ 의 공식을 통해 Vector Magnitude(VM)로 종합 할 수 있다(Santos-Lozano, et al., 2013). 측정을 위한 설정과 자료의 확인 및 분석에는 ActiLife 프로그램을 이용한다. GT9X를 ActiLife 프로그램을 통해 컴퓨터와 동기화시켜 대상자의 기초정보를 입력해 측정을 위한 기기의 설정을 할 수 있으며, 측정이 종료된 후 결과는 ActiLife로 직접 분석하거나 축별 원자료를 다운로드 받아 다양한 자료처리에 활용할 수 있다. 본 연구에서는 대상자의 우측허리 부분에 착용하여 연구를 진행하였으며 사용한 GT9X 기기특성과 착용 위치는 〈Table 2〉와 같다.

\section{2. 에너지소비량 산출}

스키선수들의 일일 그리고 활동별 에너지소비량을 산출하기 위한 공식은 〈Formula 1〉, 〈Formula 2〉와 같다. 먼저 휴식대사량 (Resting Metabolic Rate: RMR)은 대상자들의 기초정보인 신장, 체중, 나이, 성별과 Harris와 Benedict(1918) 〈Formula 1〉을 활용하여 산출하였다(Jagim, et al., 2018). 삼축가속도계 GT9X에서 수집된 에너지소비량 산출은 대상자의 체중과 축별 정보의 종합 $\mathrm{VM}$ 으로 Freedson(2011)〈Formula 2〉를 활용하여 산출하였다(Actigraph, 2021b).

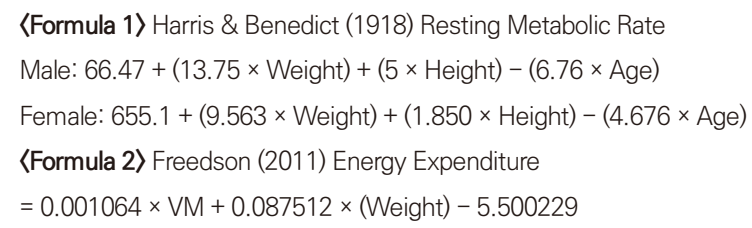

Table 2. Measure instrument

Actigraph GT9X (Actigraph, CL, USA)

\section{3. 신체활동 강도 분류}

GT9X를 통해 수집된 VM은 Freedson(1998)의 신체활동 cut point를 활용하여 분류하였다(Actigraph, 2021c). VM의 크기에 따라 'Sedentary', 'Light', 'Moderate', 'Vigorous', 'Very Vigorous'의 5 단계로 구분되며 각각의 $\mathrm{VM}$ 분류 기준은 〈Table 3 〉과 같다.

\section{METs 산출}

본 연구에서는 GT9X를 통해 수집된 VM값을 활용하여 활동 특성에 따른 METs을 시간대별로 산출하였다. 이때 Freedson(1998) METs 공식을 활용(Actigraph, 2021d)하였으며 산출 공식은 〈Formula 3〉과 같다.

〈Formula 3〉 Freedson (1998) METs $=1.439008+(0.000795 \times$ VM $)$

\section{훈련특성}

\section{1. 훈련지 특성}

스키선수 전지훈련 모니터링을 위해 프랑스와 뉴질랜드에서 실시된 훈련에 참여하여 자료를 수집하였다. 훈련지 특성은 〈Table 4〉와 같다. 프랑스 전지훈련지는 Auvergne-Rhône-Alpes에 위치한 'Les Duex Alps 3600'로 선수들이 일상생활과 체력훈련을 하는 base area는 해발 $1300 \mathrm{~m}$ 에 위치하며, base area와 스키장은 약 $2300 \mathrm{~m}$ 의 표고차를 가지고 있어 선수들은 숙소 근처에 설치된 곤돌라에 탑승하여 스키 훈련을 위한 슬로프로 이동하게 된다. 뉴질랜드 스키 훈련은 Wanaka에 위치한 'Cardrona Alpine Resort'에서 실시되었다. 뉴질랜드의 경우 훈련지와 숙소가 약 $25 \mathrm{~km}$ 정도 떨어져 있어 선수들은 차량을 이용하여 스키장에 도착하여 base area에서 훈련을 위한 준비를 마친 뒤 배정된 슬로프로 이동하여 훈련을 진행하게 된다.

\section{2. 훈련 내용 특성}

1) 스키 훈련

일반적으로 알파인 스키훈련은 기문을 설치해야 하는 종목의 특성에 따라 상대적으로 단단한 슬로프 상태를 선호하여 주로 오전에 진행된다. 기술 종목 회전, 대회전 알파인 스키선수들의 설상훈련은 프리스키, 숏폴(short pole), 회전, 대회전 훈련으로 구성된다. 프리스키는 훈련이나 시합 전 선수들의 웜 업(worm up)뿐 아니라 처음 훈련지에 도착한 경우 새롭게 바뀐 슬로프에 적응하거나 신체와

Table 3. Freedson (1998) physical activity intensity cut points

\begin{tabular}{cc}
\hline Intensity classification & $\mathrm{VM}^{*}$ cut points \\
\hline Sedentary & $0-99$ \\
Light & $100-1951$ \\
Moderate & $1952-5724$ \\
Vigorous & $5725-9498$ \\
Very vigorous & $9499-$ \\
\hline
\end{tabular}

*VM: Vector Magnitude 
장비 상태 점검, 스키 기술훈련 등 다양한 목적으로 시행된다. 또한 경기 중 많은 기문을 통과해야 하는 선수들의 기술향상을 위해 실제 경기 기문보다 짧은 숏폴을 통한 기초 훈련부터 실제 경기규격의 기문을 이용한 회전, 대회전 훈련이 진행되며 이때 숏폴과 회전, 대회전 기문은 훈련지에서 배정받은 슬로프 눈의 온도와 경사, 길이, 표고차를 고려하여 기문 숫자를 결정해 훈련 당일 지도자가 직접 설치한다. 스키훈련 구분은 〈Table 5〉와 같다.

\section{2) 체력 훈련}

모든 알파인 스키 종목은 1 2분 내외의 짧은 시간 동안 진행된다. 이때 선수는 슬로프를 내려오는 빠른 속도를 제어하며 기문을 통과하기 위한 스키 기술을 구사할 수 있어야 해서 높은 근력과 지구력, 균형감각과 순발력, 민첩성 등 종합적인 체력요소의 발달이 요구된다(Ferguson, 2010; Nilsson et al., 2018). 이로 인해 스키선수들의 체력훈련은 시즌과 비시즌기 그리고 국내 훈련과
국외훈련을 구분하여 계획되고 훈련 주기에 따라 향상시키고자 하는 체력요인과 훈련 목표가 달라지며 이때 선수들의 체력수준의 차이, 성별, 부상 여부 등의 개인차가 함께 고려된다(Lukàšek, et al., 2016; Neumayr, et al., 2003: Silva, et al., 2017).

\section{3) 훈련기록}

전지훈련 기간 스키선수들은 주로 오전에 스키 기술 훈련, 오후에는 체력향상을 위한 다양한 트레이닝으로 구성된다. 훈련의 계획과 진행에서 스키훈련의 경우 지도자가 해당일 슬로프 온도, 표고차, 경사, 길이 등의 특성과 훈련하는 스키종목에 맞추어 게이트를 설치하여 이루어지며, 오후의 체력훈련은 훈련 주기에 맞추어 체력향상 또는 유지 관리 등의 목적에 따라 구성되어 실시된다. 매일 훈련이 종료된 이후 지도자와 선수들은 각각 훈련일지를 작성하여 당일의 훈련 내용을 〈Table 6)과 같이 정리하여 기록한다. 이에 본 연구에서도 선수 및 지도자가 활용 중인 훈련일지

Table 4. Characteristic of ski training site

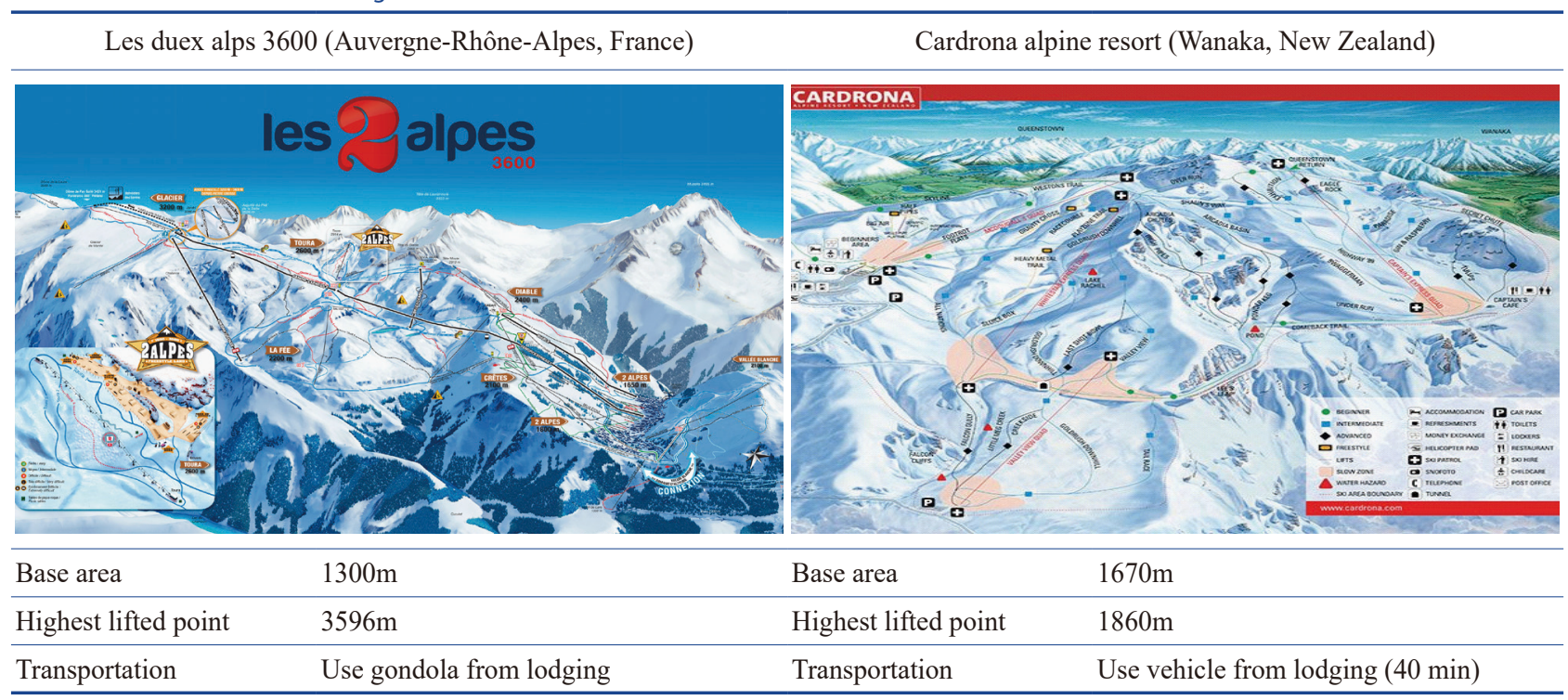

Table 5. Ski training classification

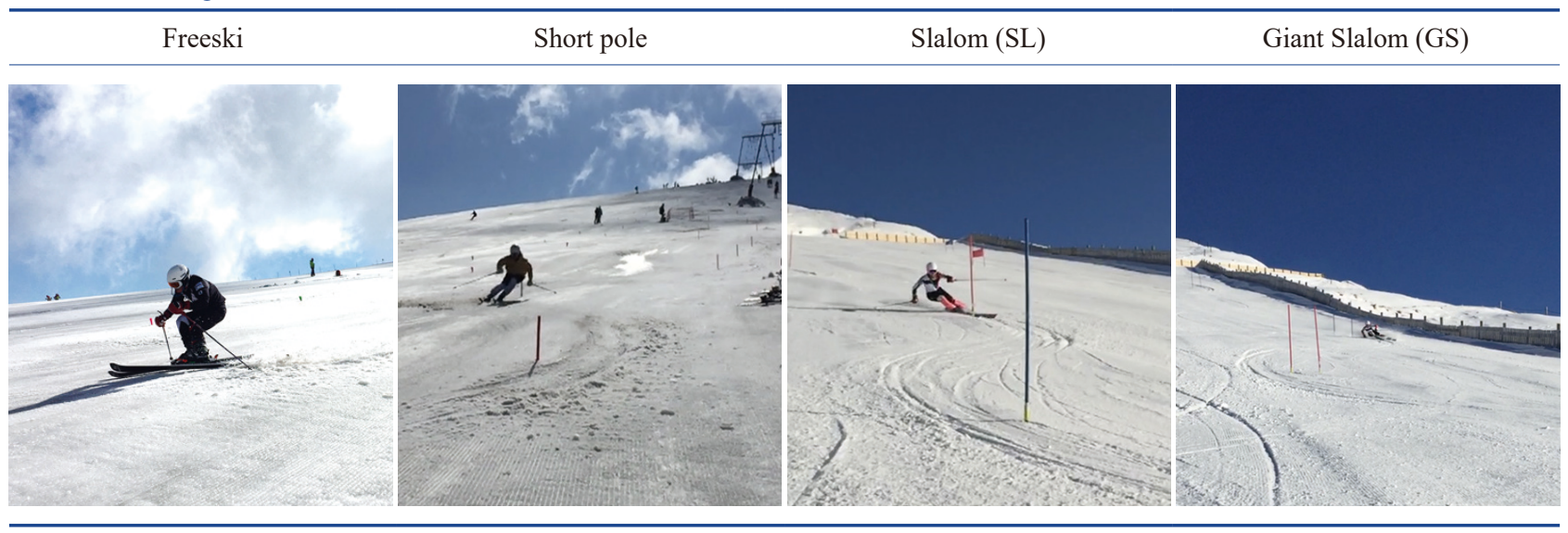


작성 방법으로 훈련 내용을 정리하여 연구에 활용하였다. 훈련 기록에는 당일의 훈련 내용에 따라 활동 구분, 활동 내용, 훈련 시간 등을 함께 작성하였으며 이를 기준으로 가속도계를 통해 측정된 자료를 분류 및 정리하였다.

\section{연구절차}

\section{1. 측정 절차}

알파인 스키 선수들의 훈련 모니터링을 진행하기 위해 선수들과 지도자들에게 신체활동 모니터의 특징과 측정 변인 및 착용 방법을 교육하고 연구 참여 동의 의사를 파악하였다. 이후 측정기기를 착용하는 것이 훈련에 지장을 주는지 확인하고, 선수들이 기기에 적응할 수 있도록 2 일의 사전 측정을 진행하였다. 사전 측정결과 선수와 지도자 모두 훈련에 영향을 미치지 않는 것으로 판단하여 본 측정을 통해 훈련 활동 정보를 수집하였다.

측정 기간은 훈련지 별로 프랑스 2017년 07월 18일 27일, 뉴질랜드는 2017년 08월 07일 8월 15일 동안 진행하였으며 활동패턴을 분석하기 위하여 측정자료 중 주말을 포함하는 총 7 일의 자료를 최종 자료로 연구에 활용하였다. 이때 연구자가 훈련에 함께 참여해 선수들의 측정 기간 동안의 훈련 내용을 정리하여 가속도계의 측정자료 분석에 참고하였다. 훈련 내용의 정리는 지도자 및 선수의 훈련일지 작성 방법을 이용해 작성하였다. 훈련 기록은 시작 및 종료 시간과 내용뿐 아니라 측정 기간 중 발생한 특이사항(예: 대회, 기상악화로 인한 훈련취소 등)이 모두 기록될 수 있도록 하여 측정자료 분석에 활용하였다.

측정 기기의 개인 분출 이전 GT9X를 ActiLife Ver 6.13.1 프로그램을 이용하여 컴퓨터와 동기화하고 신장, 체중, 나이, 인종, 착용 위치를 입력하였으며 자료수집주기(sample rate)는 $30 \mathrm{~Hz}$ 로 설정하였다. GT9X는 우측 허리 부분에 허리 클립과 탄성 밴드를 이용하여 착용하였으며(Shiroma et al., 2016), 총 7일 동안
훈련(스키, 체력) 및 일상생활에서 모두 착용할 수 있도록 하였다. 측정 기간 동안 신체활동 모니터 착용을 대상자가 잊지 않도록 연구원이 개별 연락과 훈련에 동행하여 누락되는 자료 없이 정확한 측정이 진행될 수 있도록 하였다.

\section{2. 측정자료 정리}

측정이 종료된 이후 회수된 GT9X를 ActiLife Ver 6.13.1 프로그램을 통해 컴퓨터와 동기화하고 측정 기간 동안 수집된 개별 훈련 활동 정보를 확인하였다. 이때 자료요약주기(epoch length)는 1 분으로 설정하여 1 일 24 시간 총 1440 분으로 구분된 주말을 포함한 7 일의 일별 신체활동 정보를 정리하였다. 정리된 자료는 $\mathrm{X}, \mathrm{Y}, \mathrm{Z}$ 축의 종합인 $\mathrm{VM}$ 값을 에너지소비량과 활동 분류에 사용하였다. Freedson(2011) (Actigraph, 2021b) 공식을 통해 산출된 에너지소비량은 Harris Benedict(1918)로 계산된 선수들의 개별 휴식대사량으로 보정하였다. 그리고 Freedson(1998) (Actigraph, 2021c)의 cut point를 활용하여 시간별 활동의 강도를 분류하고, Freedson(1998) (Actigraph, 2021d) 공식을 통해 시간대 별 활동의 $\mathrm{METs}$ 을 산출하였다.

\section{자료처리}

본 연구에서는 Actilife 프로그램을 통해 대상자의 신체활동 정보를 Windows Excel 파일로 변환하여 다운로드 받은 후 Window Excel 2016을 활용하여 날짜, 시간, 강도, 에너지소비량에 따라 정리하였다. 정리된 신체활동 자료는 Windows SPSS 23을 활용하여 통계 분석을 하였다. 측정일별 일일, 스키훈련과 체력훈련 동안의 에너지소비량과 활동 강도별 시간의 특성을 확인하기 위하여 기술통계를 실시하였으며, 주중·주말과 스키·체력 훈련 내용에 따른 차이 검증에는 종속표본 $t$-test를 활용하였다. 이때 유의수준 $\mathrm{a}=.05$ 로 설정하였다.

Table 6. Example of training record organization

\begin{tabular}{|c|c|c|c|c|}
\hline & 구분 & 활동구분 & 활동내용 & 훈련시간 \\
\hline \multirow{6}{*}{ 월 } & \multirow{3}{*}{ 오전 } & \multirow{3}{*}{ 설상훈련 $\mathrm{GS}^{*}$ gate } & 눈온도: 상 -6.3 , 중 -6.1 , 하 -6.9 & 8:00 - 8:30 웜업 및 스케이팅활주 \\
\hline & & & 인터벌: 상단 $24 \mathrm{~m}$, 하단 $25 \mathrm{~m}$ & 8:30 - 9:00 프리스키 \\
\hline & & & 게이트 수: 25개 24턴 & $9: 00-12: 30$ 게이트 훈련(30분 휴식) \\
\hline & \multirow{3}{*}{ 오후 } & \multirow{3}{*}{ 지상훈련 } & $12 \mathrm{~min}$ run/ergo $2000 \mathrm{~m}\left(80^{`} 90 \%\right)$ & \multirow{3}{*}{$15: 30-18: 00$} \\
\hline & & & Core strength (slide \& oblique) & \\
\hline & & & Function training & \\
\hline \multirow{5}{*}{ 화 } & \multirow{3}{*}{ 오전 } & \multirow{3}{*}{ 설상훈련 GS* gate } & 눈온도: 상 -3.2 , 중 -3.7 , 하 -2.7 & 8:00 - 8:30 웜업 및 스케이팅활주 \\
\hline & & & 인터벌: 상단 $24 \mathrm{~m}$, 하단 $25 \mathrm{~m}$ & 8:30 - 9:00 프리스키 \\
\hline & & & 게이트 수: 25개 23턴 & 9:00 - $12: 30$ 게이트 훈련(30분 휴식) \\
\hline & \multirow{2}{*}{ 오후 } & \multirow{2}{*}{ 지상훈련 } & Stability \& mobility & $-15 \cdot 30-18 \cdot 00$ \\
\hline & & & Function training (ski motion drills) & $-15.30-18.00$ \\
\hline \multirow{6}{*}{ 수 } & \multirow{3}{*}{ 오전 } & \multirow{3}{*}{ 설상훈련 GS* gate } & 눈온도: 상 -7.6 , 중 -7.6 , 하 -7.3 & 8:00 - 8:30 윔업 및 스케이팅활주 \\
\hline & & & 인터벌: 상단 $24 \mathrm{~m}$, 하단 $25 \mathrm{~m}$ & 8:30 - 9:00 프리스키 \\
\hline & & & 게이트 수: 25개 23턴 & 9:00 -12:30 게이트 훈련(30분 휴식) \\
\hline & \multirow{3}{*}{ 오후 } & \multirow{3}{*}{ 개별운동, 컨디셔닝 } & 개별 컨디셔닝 및 회복, 휴식 & \multirow{3}{*}{$15: 30-18: 00$} \\
\hline & & & 개별 보강 및 강화운동 & \\
\hline & & & 개별 스트레칭 & \\
\hline
\end{tabular}

*GS: Giant Slalom 


\section{연구결과}

본 연구는 삼축가속도계를 활용한 알파인 스키선수들의 전지훈련 모니터링을 통해 훈련기간 동안 나타나는 다양한 신체활동 특성을 분석하는데 목적이 있다. 이에 본 연구의 결과 제시는 측정기간 동안 진행된 우리나라 알파인 스키선수들의 프랑스와 뉴질랜드의 일별 전지훈련 내용을 소개하고, 이때 나타나는 강도별 활동시간과 신체활동 패턴으로 구성하였다. 또한 이를 통해 나타나는 총 에너지소비량과 주중·주말과 스키·체력 훈련에 따른 에너지소비량의 차이 분석 결과를 제시하였다.

\section{프랑스 전지훈련}

\section{1. 프랑스 주간 훈련특성}

프랑스 주간 전지훈련 특성은 〈Table 7〉과 같다. 훈련은 주중과 주말의 구분 없이 오전 스키, 오후 체력훈련으로 운영되며 주중 하루의 스키훈련 휴식(day off)시간을 가지고 있는 것으로 나타났으며 이날 체력훈련은 예정대로 진행되었다. 스키훈련의 경우 선수들은 오전 8:00에 곤돌라에 탑승하여 슬로프로 이동하였다. 훈련 시간은 8:40 12:00로 계획되었으나 당일 훈련 내용과 날씨에 따라 적절하게 조정되어 운영되었다. 스키훈련 내용은 프리스키, 숏폴, 회전(SL), 대회전(GS)훈련을 당일 슬로프와 선수의 개별 몸 상태에 맞추어 적절하게 배정하여 실시하였으며 선수들은 훈련 준비를 위한 3 4회 프리스키를 진행하고 정해진 슬로프에서 6 7회 반복적인 훈련을 실시하였다.

오전 스키훈련이 종료된 이후 선수들은 13:00에 숙소로 이동하여 점심식사 및 휴식을 취한 후 $14: 30$ 분부터 $17: 30$ 분까지 체력훈련에 참여하였다. 체력훈련은 인터벌, 균형감각, 스키 자세훈련 등의 내용으로 구성되며, 체력 수준 및 부상 등의 특성에 따라 개별화 프로그램으로 진행되었다. 오후 훈련이 종료된 후 선수들은 저녁식사
및 휴식을 취하였으며 19:00 20:00 선수 및 지도자들의 미팅을 통해 당일 훈련 내용을 정리하고, 다음 날 훈련을 준비하였다.

\section{2. 프랑스 주간 활동 강도 패턴}

〈Table 7〉의 훈련 내용에 따라서 나타나는 프랑스 전지훈련의 일일 활동 강도 특성은 〈Table 8〉, 전체적인 일별 활동 강도 패턴은 〈Figure 1〉과 같다. 스키 훈련이 진행된 오전의 활동의 강도는 최소 $1.44 \mathrm{METs}$ 에서 최대 $7.51 \mathrm{METs}$ 범위로 나타났으며 세부 훈련별로 프리스키 위주의 훈련이 이루어진 월·화·금요일(1.44 6.67METs) 보다 게이트 훈련이 주를 이룬 수·토·일요일(1.44 7.51METs)의 활동 강도가 상대적으로 다소 높은 것으로 나타났다. 스키훈련 동안의 활동 강도 패턴의 경우 훈련 내용과는 구분 없이 선수들이 슬로프를 내려오는 짧은 시간 동안 높은 강도 활동이 훈련시간 중 반복적으로 나타나는 형태를 보였다.

체력훈련이 이루어진 오후 훈련은 최소 $1.44 \mathrm{METs}$ 에서 8.40METs의 강도 범위에서 훈련이 이루어지고 있었다. 체력 훈련 강도의 경우 당일 훈련 내용에 따라 저강도에서 고강도로 지속적으로 강도를 증가시키거나 고강도 훈련으로 시작하여 점차적으로 강도를 낮추며 훈련을 마무리하는 등 다양한 형태로 훈련이 진행되고 있음을 확인할 수 있었다. 스키훈련이 없는 목요일의 경우 오전 시간 스키 선수들은 $1.44 \sim 3.36 \mathrm{METs}$ 의 가벼운 활동을 하는 것으로 나타났으며 이날 체력훈련 역시 1.44 3.22METs로 다소 낮은 강도를 보였다.

〈Table 7〉, 〈Table 8〉, 〈Figure 1〉에 정리된 주간 훈련 내용과 강도 및 패턴을 종합적으로 살펴보았을 때 스키 선수들의 훈련은 주중과 주말의 구분 없이 훈련시간 활동 강도가 증가하는 경향을 보였다. 특히, 스키 훈련의 경우 강도는 높으나 지속시간이 짧은 형태의 활동이 반복적으로 나타나는 특징이 있었으며 체력훈련의 경우 당일 훈련 내용에 따라서 다양한 패턴의 강도 변화를 나타냈다, 또한 일일 총 훈련 강도는 스키훈련이 높은 강도로 실시된 경우 상대적으로 체력훈련 강도는 낮은 강도로 구성되어 진행되는 것으로 나타났다.

Table 7. Weekly training contents (France group)

\begin{tabular}{|c|c|c|c|c|}
\hline \multicolumn{5}{|c|}{ Les Duex Alps, France } \\
\hline & & Type of training & Training contents & Training time \\
\hline \multirow{2}{*}{ Mon } & $\mathrm{AM}$ & Freeski & Freeski, basic ski skill training & 08:00 (on board gondola), $08: 40-10: 30$ \\
\hline & PM & Individual fitness training & Individual fitness training or rest & $14: 30-17: 30$ \\
\hline \multirow{3}{*}{ Tue } & \multirow{2}{*}{$\mathrm{AM}$} & Ski training: Short pole & Short pole: 37 turn & 08:00 (on board gondola), $08: 40-10: 20$ \\
\hline & & Freeski & Freeski, basic ski skill training & $10: 30-11: 30$ \\
\hline & PM & Individual fitness training & Interval, balance, ski posture & $14: 30-17: 30$ \\
\hline \multirow{3}{*}{ Wed } & \multirow{2}{*}{$\mathrm{AM}$} & Freeski & Freeski, basic ski skill training & 08:00 (on board gondola), $08: 40-10: 30$ \\
\hline & & Gate training & Slalom (SL), Giant Slalom (GS) & SL: $11: 00-11: 30$, GS: $11: 30-12: 30$ \\
\hline & PM & Individual fitness training & Interval, balance, ski posture & $14: 30-17: 30$ \\
\hline \multirow{2}{*}{ Thu } & $\mathrm{AM}$ & Day off & Day off & Day off \\
\hline & PM & Individual fitness training & Interval, balance, ski posture & $14: 30-17: 30$ \\
\hline \multirow{2}{*}{ Fri } & $\mathrm{AM}$ & Freeski & Freeski, basic ski skill training & 08:00 (on board gondola), $08: 40-11: 00$ \\
\hline & PM & Individual fitness training & Interval, balance, ski posture & $14: 30-17: 30$ \\
\hline \multirow{2}{*}{ Sat } & $\mathrm{AM}$ & Ski training: Short pole & Short pole: 37 turn & 08:00 (on board gondola), $08: 40-12: 00$ \\
\hline & PM & Individual fitness training & Interval, balance, ski posture & $14: 30-17: 30$ \\
\hline \multirow{2}{*}{ Sun } & $\mathrm{AM}$ & Ski training: Slalom & Slalom: 37 turn & 08:00 (on board gondola), $08: 40-11: 00$ \\
\hline & PM & Selective training time & Individual fitness training or rest & $14: 30-17: 30$ \\
\hline
\end{tabular}



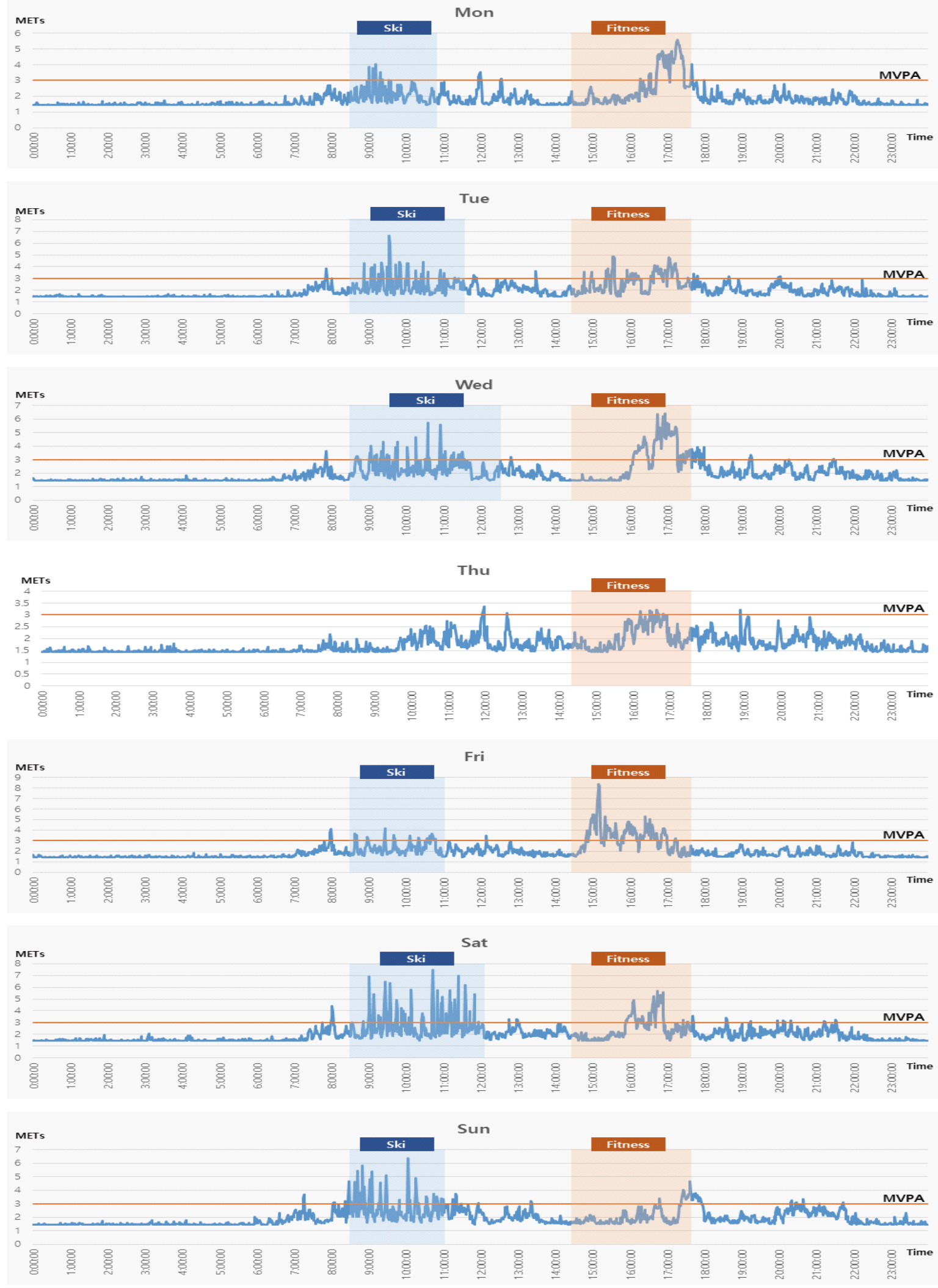

Fig. 1. Daily intensity patterns (France group) (METs) 
Table 8. Daily training intensity (France group)

\begin{tabular}{cccccc}
\hline \multirow{2}{*}{ Mon } & & Min & Max & $M$ & SD \\
\cline { 2 - 6 } & Ski & 1.45 & 4.05 & 2.03 & 0.48 \\
\cline { 2 - 6 } Tue & Fitness & 1.44 & 5.59 & 2.41 & 1.15 \\
\cline { 2 - 6 } & Ski & 1.50 & 6.67 & 2.35 & 0.07 \\
\hline \multirow{2}{*}{ Wed } & Fitness & 1.44 & 4.87 & 2.55 & 0.05 \\
\cline { 2 - 6 } & Ski & 1.46 & 5.76 & 2.31 & 0.07 \\
\hline \multirow{2}{*}{ Thu } & Fitness & 1.44 & 6.43 & 2.58 & 0.05 \\
\cline { 2 - 6 } & Day off & 1.44 & 3.36 & 1.81 & 0.07 \\
\hline \multirow{2}{*}{ Fri } & Fitness & 1.44 & 3.22 & 2.05 & 0.05 \\
\cline { 2 - 6 } & Ski & 1.44 & 4.15 & 2.18 & 0.52 \\
\hline \multirow{2}{*}{ Sat } & Fitness & 1.44 & 8.40 & 3.09 & 1.26 \\
\cline { 2 - 6 } & Ski & 1.46 & 7.51 & 2.71 & 1.11 \\
\hline \multirow{2}{*}{ Sun } & Fitness & 1.44 & 5.68 & 2.47 & 0.98 \\
\cline { 2 - 6 } & Ski & 1.45 & 6.39 & 2.55 & 0.77 \\
\hline
\end{tabular}

프랑스 주간 강도별 활동시간

일상생활과 훈련을 모두 포함하는 1 일 1440 분 중 일일 활동 강도별 시간 및 비율을 정리한 결과는 〈Table 9〉, 〈Figure 2〉와 같다. 활동 강도 분류 중 주중과 주말의 구분 없이 금요일 $790.50 \pm 81.06 \mathrm{~min} /$

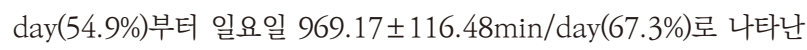
수면시간을 포함한 'Sedentary' 가 가장 높은 비율을 차지하고 있었으며, 일요일 $367.67 \pm 95.14 \mathrm{~min} / \mathrm{day}(25.5 \%) \sim$ 토요일 $502 \pm 49.98 \mathrm{~min} / \mathrm{day}(34.9 \%)$ 의 범위로 나타난 $1.5 \sim 2.9 \mathrm{METs}$ 의 'Light' 활동이 그 다음으로 높은 비율을 보이고 있었다.

$3 \mathrm{METs}$ 이상의 중·고강도 활동의 경우 3 5.9METs의 'Moderate'는 일요일이 $83.83 \pm 35.02 \mathrm{~min} / \mathrm{day}(5.8 \%)$ 로 가장 낮았고, 목요일이 $141.17 \pm 29.19$ (9.8\%)으로 가장 높게 나타났다. 6METs 이상 고강도 활동은 수요일이 $3.33 \pm 4.04 \mathrm{~min} / \mathrm{day}(0.2 \%)$ 로 가장 낮았고 화요일이 $31 \pm 8.60 \mathrm{~min} / \mathrm{day}(2.2 \%)$ 로 가장 높았다. 주중 활동 강도 중 중강도 이상(MVPA)의 활동 시간과 총 강도를 살펴보면 주중 중강도 시간은 $836.67 \mathrm{~min} / \mathrm{week}$ 주중 총 중강도 활동은 $3259.72 \mathrm{METs} /$ week였으며 주중 총 고강도 시간은 $135.17 \mathrm{~min} / \mathrm{week}$, 총 고강도 활동은 $1092.05 \mathrm{METs} / w e e k$ 로 나타났다.

Table 9. Mean daily time spent on different activity intensity (France group)

$(\min )$

\begin{tabular}{|c|c|c|c|c|c|c|c|c|c|c|c|c|c|c|}
\hline & \multicolumn{2}{|l|}{ Mon } & \multicolumn{2}{|l|}{ Tue } & \multicolumn{2}{|l|}{ Wed } & \multicolumn{2}{|l|}{ Thu } & \multicolumn{2}{|l|}{ Fri } & \multicolumn{2}{|l|}{ Sat } & \multicolumn{2}{|l|}{ Sun } \\
\hline & $M \pm S D$ & $\%$ & $M \pm S D$ & $\%$ & $M \pm S D$ & $\%$ & $M \pm S D$ & $\%$ & $M \pm S D$ & $\%$ & $M \pm S D$ & $\%$ & $M \pm S D$ & $\%$ \\
\hline $\begin{array}{l}\text { Sleep and } \\
\text { sedentary }\end{array}$ & $\begin{array}{c}820.17 \\
+118.34 \\
\end{array}$ & 57.0 & $\begin{array}{r}818.17 \\
\pm 37.87 \\
\end{array}$ & 56.8 & $\begin{array}{c}967.33 \\
\pm 143.50\end{array}$ & 67.2 & $\begin{array}{r}831.00 \\
\pm 92.02 \\
\end{array}$ & 57.7 & $\begin{array}{r}790.50 \\
\pm 81.06 \\
\end{array}$ & 54.9 & $\begin{array}{r}795.17 \\
\pm 47.18\end{array}$ & 55.2 & $\begin{array}{c}969.17 \\
\pm 116.48 \\
\end{array}$ & 67.3 \\
\hline Light & $\begin{array}{c}467.83 \\
\pm 88.11 \\
\end{array}$ & 32.5 & $\begin{array}{l}467.00 \\
\pm 51.61 \\
\end{array}$ & 32.4 & $\begin{array}{l}378.00 \\
\pm 96.74\end{array}$ & 26.3 & $\begin{array}{r}446.83 \\
\pm 81.74 \\
\end{array}$ & 31.0 & $\begin{array}{l}489.00 \\
\pm 61.59\end{array}$ & 34.0 & $\begin{array}{r}502.00 \\
\pm 49.98 \\
\end{array}$ & 34.9 & $\begin{array}{r}367.67 \\
\pm 95.14 \\
\end{array}$ & 25.5 \\
\hline Moderate & $\begin{array}{r}136.00 \\
\pm 29.97 \\
\end{array}$ & 9.4 & $\begin{array}{r}123.83 \\
\pm 34.54\end{array}$ & 8.6 & $\begin{array}{c}93.00 \\
\pm 48.15\end{array}$ & 6.5 & $\begin{array}{r}141.17 \\
\pm 29.19\end{array}$ & 9.8 & $\begin{array}{r}132.50 \\
\pm 31.23\end{array}$ & 9.2 & $\begin{array}{r}126.33 \\
\pm 32.28\end{array}$ & 8.8 & $\begin{array}{c}83.83 \\
\pm 35.02 \\
\end{array}$ & 5.8 \\
\hline Vigorous & $\begin{array}{r}16.00 \\
\pm 6.29 \\
\end{array}$ & 1.1 & $\begin{array}{r}31.00 \\
\pm 8.60 \\
\end{array}$ & 2.2 & $\begin{array}{c}3.33 \\
\pm 4.04 \\
\end{array}$ & 0.2 & $\begin{array}{c}21.00 \\
\pm 11.92 \\
\end{array}$ & 1.5 & $\begin{array}{l}28.00 \\
\pm 4.77 \\
\end{array}$ & 1.9 & $\begin{array}{c}16.50 \\
\pm 14.65 \\
\end{array}$ & 1.1 & $\begin{array}{c}19.33 \\
\pm 16.31 \\
\end{array}$ & 1.3 \\
\hline \multicolumn{5}{|c|}{ Weekly total Moderate time (min/week) } & 836.67 & & \multicolumn{6}{|c|}{ Weekly total Moderate METs (METs/week) } & \multicolumn{2}{|l|}{3259.72} \\
\hline \multicolumn{5}{|c|}{ Weekly total Vigorous time (min/week) } & 135.17 & & \multicolumn{6}{|c|}{ Weekly total Vigorous METs (METs/week) } & \multicolumn{2}{|l|}{1092.05} \\
\hline
\end{tabular}

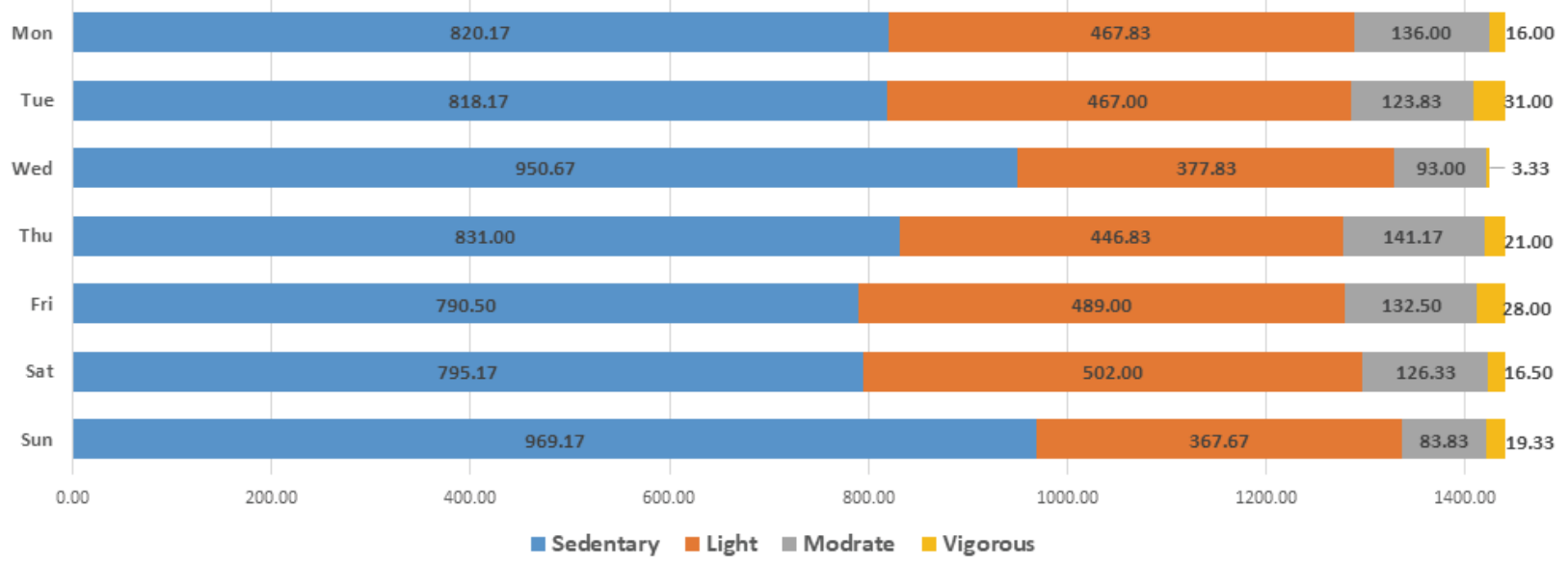

Fig. 2. Mean daily time spent on different activity intensity (France group) (min) 
전지훈련 기간 동안 나타나는 일상생활과 훈련에 대한 강도별 활동시간에 대한 분석결과 수면을 포함한 'Sedentary'의 비율이 가장 높았으며 다음으로 'Light', 'Moderate', 'Vigorous'의 순서였다. 이중 중강도 이상 활동은 훈련 내용에 따라 일별로 다소 차이가 있었지만 약 6 10\% 내외의 비율을 차지하고 있었으며 주당 총 활동 시간과 강도는 매우 높게 나타났다.

\section{프랑스 훈련기간 에너지소비량 차이}

〈Table 10〉은 프랑스 일별 에너지소비량을 정리한 것으로 일일 에너지소비량은 오전에 스키훈련을 실시했음에도 불구하고 수요일이 $2295.13 \pm 301.32 \mathrm{kcal}$ 로 가장 낮았고 토요일이 $2797.46 \pm 289.66 \mathrm{kcal}$ 로 가장 높게 나타났다. 스키훈련 시 에너지소비량은 회전, 대회전 훈련을 함께 진행한 수요일이 $404.03 \pm 58.59 \mathrm{kcal}$ 로 가장 낮았고 회전 솟폴 훈련을 실시한 토요일이 $685.55 \pm 87.01 \mathrm{kcal}$ 로 가장 높았다. 체력훈련 시 에너지소비량은 오전에 스키훈련을 하지 않은 목요일이 $671.90 \pm 135.68 \mathrm{kcal}$ 로 가장 높았으며, 회전 게이트 훈련을 한 일요일이 $343.09 \pm 64.48 \mathrm{kcal}$ 로 가장 낮게 나타났다.

프랑스 훈련기간 중 에너지소비량의 차이는 〈Table 11 〉과 같다. 주중과 주말 일별 총 에너지소비량 차이를 살펴보면 주중 평균 $2574.20 \pm 254.16 \mathrm{kcal}$, 주말 평균 $2737.58 \pm 255.31 \mathrm{kcal}$ 였으며 $\mathrm{p}=$.009로 나타나 통계적으로 유의한 차이가 나타났다. 주간 스키훈련 에너지소비량의 차이는 주중 스키훈련 평균 $509.88 \pm 41.55 \mathrm{kcal}$, 주말 스키훈련 평균 $663.84 \pm 76.68 \mathrm{kcal}$ 로 나타났으며 $\mathrm{p}=.002$ 로 통계적으로 유의한 차이가 있었다. 주간 체력훈련의 경우 주중 평균 $510.03 \pm 76.45 \mathrm{kcal}$, 주말 체력훈련 평균 $411.90 \pm 53.20 \mathrm{kcal}$ 이었으며 $\mathrm{p}=.019$ 로 통계적으로 유의한 차이가 있었다. 일주일간 실시 된 스키훈련의 에너지소비량은 평균 $553.87 \pm 46.06 \mathrm{kcal}$, 체력훈련의 에너지소비량은 $481.99 \pm 62.90 \mathrm{kcal}$ 으로 $p=.08$ 에서 유의미한 차이는 없는 것으로 분석되었다.

Table 10. Daily energy expenditure (France group)

(kcal)

\begin{tabular}{|c|c|c|c|c|c|c|}
\hline & \multicolumn{6}{|c|}{ Energy expenditure } \\
\hline & \multicolumn{2}{|c|}{ Daily total } & \multicolumn{2}{|c|}{ Ski training } & \multicolumn{2}{|c|}{ Fitness training } \\
\hline & $M$ & $S D$ & $M$ & $S D$ & $M$ & $S D$ \\
\hline Mon & 2674.72 & 292.12 & 589.42 & 79.86 & 492.55 & 172.35 \\
\hline Tue & 2766.04 & 222.65 & 563.91 & 35.96 & 530.72 & 66.25 \\
\hline Wed & 2295.13 & 301.32 & 404.02 & 58.59 & 372.72 & 169.85 \\
\hline Thu & 2699.94 & 330.41 & 521.86 & 39.93 & 671.90 & 135.68 \\
\hline Fri & 2435.17 & 307.05 & 470.20 & 162.88 & 482.23 & 170.28 \\
\hline Sat & 2797.46 & 289.66 & 685.55 & 87.01 & 480.70 & 61.22 \\
\hline Sun & 2677.71 & 285.01 & 642.13 & 69.91 & 343.09 & 64.48 \\
\hline
\end{tabular}

\section{뉴질랜드 전지훈련}

\section{1. 뉴질랜드 주간 훈련 특성}

뉴질랜드 주간 전지훈련 일정은 〈Table 12〉와 같다. 뉴질랜드 훈련 역시 주중·주말로 주간일정을 구분하기 보다는 훈련 내용에 따라 주중에 스키훈련 휴식(day off)을 포함하고 있었다. 특히, 'New Zealand National Championships And Coronet Cup'이 진행된 수·목요일의 전후인 화요일과 금요일에는 선수들의 체력적 고려와 적절한 휴식을 위해 스키훈련은 실행하지 않고 지상훈련과 웨이트 트레이닝 위주로 훈련이 실시되었다.

전체적인 훈련은 프랑스와 유사하게 오전에 스키훈련, 오후에 체력훈련을 진행하는 형태로 진행되었다. 스키훈련의 경우 주로 오전 8:00 12:00로 계획되었으며 오후 체력훈련은 15:00 17:00로 진행되었다. 스키훈련 내용은 회전(SL), 대회전(GS)으로 계획되었으나 측정 기간 동안에는 주중일정에 포함된 대회 종목에 맞추어 회전 위주의 기문(gate) 훈련이 실시되었다. 체력훈련은 선수들의 개별 특성을 고려하여 체력향상보다는 유지를 위한 내용으로 구성되었으며, 부상관리와 재활을 함께 고려하여 지상 훈련 및 웨이트 트레이닝 프로그램이 진행되었다.

\section{뉴질랜드 주간 활동 강도 패턴}

〈Table 12〉의 일정에 따라 나타나는 스키·체력훈련과 일별 활동 강도 특성은 〈Table 13〉, 활동 강도 패턴의 변화는 〈Figure 3〉와 같으며 뉴질랜드의 측정 결과의 경우 자료수집 기간 중에 스키와 체력훈련, 대회, 휴식일 구분해서 내용 및 활동 패턴을 모두 확인할 수 있었다. 스키훈련이 진행된 월, 토, 일요일의 경우 최소 1.44 최대 8.68METs 범위의 활동 강도를 나타났으며, 대회에 참가한 수요일과 목요일은 1.44 8.26METs의 활동 강도를 보였다. 뉴질랜드의 스키훈련, 대회 참가 시 나타나는 활동 강도의 패턴 변화는 프랑스와 유사하게

Table 11. Difference of energy expenditure (France group) (kcal)

\begin{tabular}{|c|c|c|c|c|c|}
\hline & $M$ & $S D$ & $t$ & $d f$ & $p$ \\
\hline Weekday total & 2574.20 & 254.16 & \multirow{2}{*}{-4.106} & \multirow{2}{*}{5} & \multirow{2}{*}{.009} \\
\hline Weekend total & 2737.58 & 255.31 & & & \\
\hline Weekday ski training & 509.88 & 41.55 & \multirow{2}{*}{-6.057} & \multirow{2}{*}{5} & \multirow{2}{*}{.002} \\
\hline Weekend fitness training & 663.84 & 76.68 & & & \\
\hline Weekday ski training & 510.03 & 76.45 & \multirow{2}{*}{3.389} & \multirow{2}{*}{5} & \multirow{2}{*}{.019} \\
\hline Weekend fitness training & 411.90 & 53.20 & & & \\
\hline Ski training & 553.87 & 46.06 & \multirow{2}{*}{2.186} & \multirow{2}{*}{5} & \multirow{2}{*}{.080} \\
\hline Fitness training & 481.99 & 62.90 & & & \\
\hline
\end{tabular}


선수들이 스키를 타는 짧은 시간 동안 활동 강도가 높게 증가하였다가 다시 낮아지는 형태가 반복적으로 나타났다. 이러한 패턴은 월요일, 토요일 같이 스키훈련을 하는 동안은 계획된 훈련 시간 중 일정한 간격을 두고 지속적으로 반복되고 있었으나 수요일, 목요일 대회 일정의 경우 대회를 위한 코스 점검(inspection)과 정규 슬로프에서 이루어지는 공식훈련(official training), 예선이 진행된 시간 동안 고강도 활동이 반복적으로 나타났다가 본선이 이루어지기 전까지 오랜 시간동안은 높아지지 않은 형태를 보이고 있었다. 체력훈련 강도의 경우 최소 $1.44 \mathrm{METs}$ 에서 최대 $7.86 \mathrm{METs}$ 의 범위에서 진행되고 있었으며 강도의 변화는 당일 스키훈련 또는 대회일정을 기반으로 계획된 체력훈련 내용에 따라 다른 형태를 보였다.

주간 훈련 강도를 종합적으로 살펴볼 때 전체적인 훈련 계획은 스키훈련의 강도에 따라 체력훈련 강도를 조절하는 형태로 이루어지고 있었으며, 특히 대회의 전·후 선수들의 체력 및 컨디션 조절을 위해 적절한 휴식을 고려한 트레이닝을 실시하는 것으로 나타났다.

일상생활과 훈련일정을 모두 포함한 뉴질랜드 주간 훈련의 일일 강도별 활동시간 분류는 〈Table 14〉, 〈Figure 4〉와 같다. 일별 활동 시간 중 가장 높은 비율은 수면시간과 'Sedentary'가 차지하고 있었는데 화요일이 $1069.80 \pm 100.73 \mathrm{~min} / \mathrm{day}(74.3 \%)$ 으로 가장 높았고, 월요일이 $829 \pm 62.92 \mathrm{~min} / \mathrm{day}(57.6 \%)$ 로 가장 낮게 나타났다. 'Light'의 경우 화요일이 $283.8 \pm 88.16 \mathrm{~min} / \mathrm{day}(19.7 \%)$ 으로 가장
Table 13. Daily training intensity (New Zealand group) (METs)

\begin{tabular}{|c|c|c|c|c|c|}
\hline & & Min & $\operatorname{Max}$ & $M$ & $S D$ \\
\hline \multirow{2}{*}{ Mon } & Ski & 1.44 & 7.30 & 2.68 & 1.36 \\
\hline & Fitness & 1.46 & 5.75 & 2.38 & 0.72 \\
\hline \multirow{2}{*}{ Tue } & Day off & 1.44 & 2.29 & 1.61 & 0.18 \\
\hline & Fitness & 1.44 & 4.61 & 2.35 & 0.94 \\
\hline \multirow{2}{*}{$\begin{array}{c}\text { Wed } \\
\left(\text { comp }^{*}\right)\end{array}$} & Ski & 1.44 & 8.26 & 2.21 & 0.07 \\
\hline & Fitness & 1.44 & 6.56 & 2.67 & 0.05 \\
\hline \multirow{2}{*}{$\begin{array}{c}\text { Thu } \\
\left.\text { (comp }{ }^{*}\right)\end{array}$} & Ski & 1.44 & 5.78 & 2.21 & 0.82 \\
\hline & Fitness & 1.45 & 5.20 & 2.10 & 0.64 \\
\hline \multirow{2}{*}{ Fri } & Day off & 1.44 & 2.33 & 1.52 & 0.13 \\
\hline & Fitness & 1.44 & 5.12 & 1.99 & 0.69 \\
\hline \multirow{2}{*}{ Sat } & Ski & 1.44 & 8.68 & 2.55 & 1.16 \\
\hline & Fitness & 1.44 & 6.70 & 2.27 & 1.15 \\
\hline \multirow{2}{*}{ Sun } & Ski & 1.44 & 3.24 & 1.64 & 0.33 \\
\hline & Fitness & 1.44 & 7.86 & 1.95 & 0.98 \\
\hline
\end{tabular}

*comp: cononet peak competition

Table 12. Weekly training contents (New Zealand group)

\begin{tabular}{|c|c|c|c|c|}
\hline \multicolumn{5}{|c|}{ Cardrona, New Zealand } \\
\hline & & Type of training & Training contents & Training time \\
\hline \multirow{2}{*}{ Mon } & $\mathrm{AM}$ & Gate training & Slalom (SL): 55 turn & 07:30 departed from lodging (use vehicle) $-12: 00$ \\
\hline & PM & Fitness training & Fitness and weight training & $15: 00-17: 00$ \\
\hline \multirow{2}{*}{ Tue } & $\mathrm{AM}$ & Day off & Day off & Day off \\
\hline & PM & Fitness training & Fitness and weight training & $15: 00-17: 00$ \\
\hline \multirow{2}{*}{ Wed } & $\mathrm{AM}$ & $\begin{array}{l}\text { Cononet peak competition: } \\
\text { canceled (bad weather) }\end{array}$ & $\begin{array}{l}\text { Cononet peak competition: } \\
\text { canceled (bad weather) }\end{array}$ & $\begin{array}{l}\text { 06:00 departed from lodging (use vehicle) } \\
\text { 8:00 - Freeski }\end{array}$ \\
\hline & PM & Fitness training & Fitness and weight training & $15: 00-17: 00$ \\
\hline \multirow{2}{*}{ Thu } & $\mathrm{AM}$ & $\begin{array}{c}\text { Cononet peak competition } \\
\text { Slalom }\end{array}$ & $\begin{array}{l}\text { Cononet peak competition: } \\
\text { Slalom }\end{array}$ & $\begin{array}{l}\text { Qualifier: 8:00- } \\
\text { Final: } 12: 30-\end{array}$ \\
\hline & PM & Fitness training & Fitness and weight training & $15: 00-17: 00$ \\
\hline \multirow{2}{*}{ Fri } & $\mathrm{AM}$ & Day off & Day off & Day off \\
\hline & PM & Fitness training & Fitness and weight training & $15: 00-17: 00$ \\
\hline \multirow{2}{*}{ Sat } & $\mathrm{AM}$ & Gate training & Slalom (SL): 55 turn & 07:30 departed from lodging (use vehicle) $-12: 00$ \\
\hline & PM & Fitness training & Fitness and weight training & $15: 00-17: 00$ \\
\hline \multirow{2}{*}{ Sun } & $\mathrm{AM}$ & Freeski & Freeski & $12: 00-$ \\
\hline & PM & Fitness training & Fitness and weight training & $15: 00-17: 00$ \\
\hline
\end{tabular}



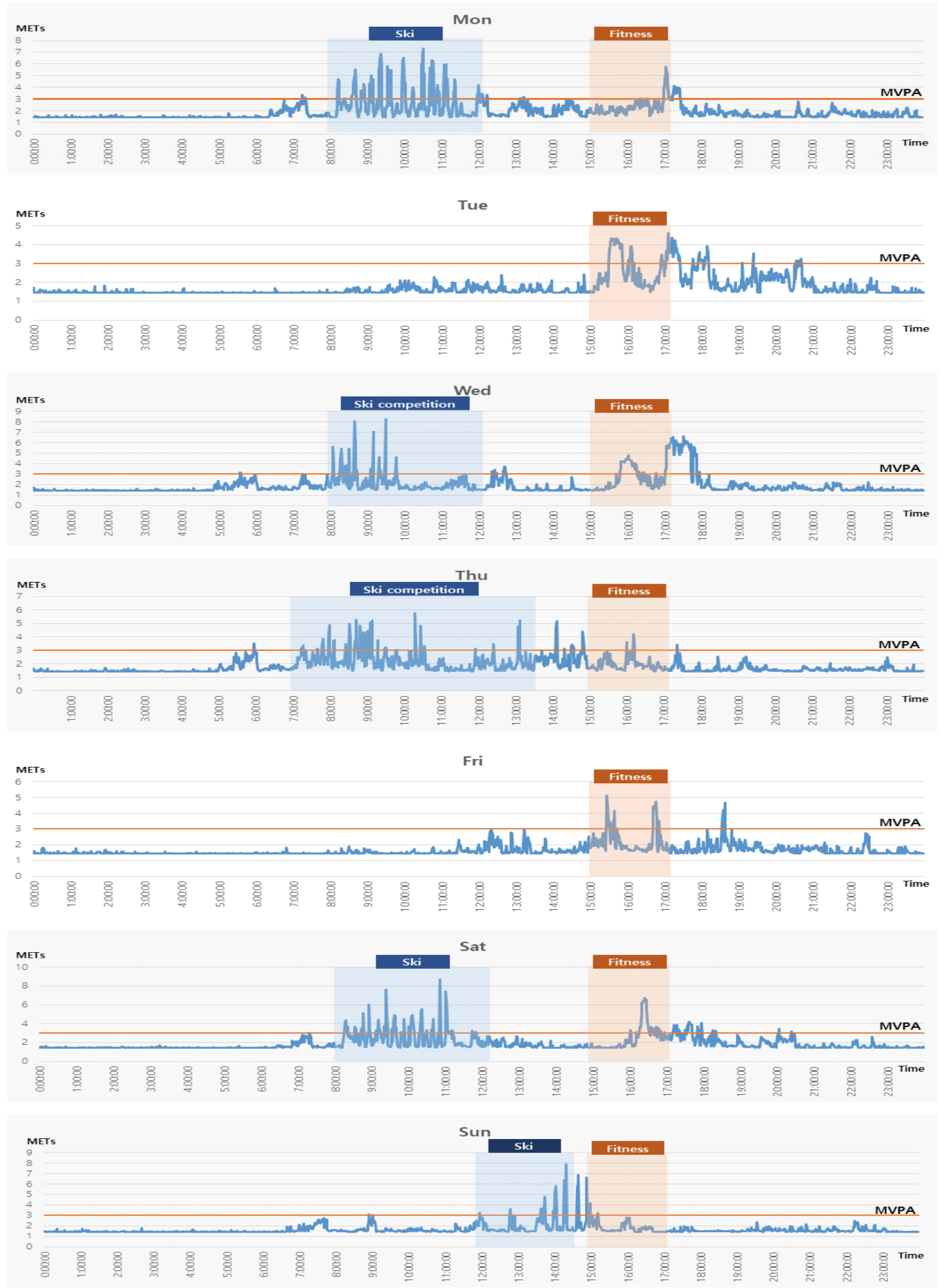

Fig. 3. Daily intensity patterns (New Zealand group) (METs) 


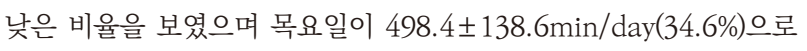
제일 높았다. 중강도 이상의 활동의 경우 3 5.9METs의 'Moderate' 비율은 월요일이 $130.40 \pm 39.95 \mathrm{~min} / \mathrm{day}(9.1 \%)$ 으로 가장 높았으며 일요일이 $47.6 \pm 16.29 \mathrm{~min} / \mathrm{day}(3.3 \%)$ 으로 가장 낮은 비율을 차지하고 있었다. 6METs 이상 'Vigorous'는 일별로 가장 낮은 비율을 보이고 있었는데 특히 금요일이 $2.5 \pm 2.12 \mathrm{~min} / \mathrm{day}(0.2 \%)$ 로 제일 낮은 비율 보였으며 수요일이 $48.2 \pm 6.06 \mathrm{~min} / \mathrm{day}(3.3 \%)$ 으로 가장 높게 나타났다. 주중 활동 강도 중 중강도 이상(MVPA) 활동 시간 및 총 강도는 주중 중강도 시간 $596 \mathrm{~min} / \mathrm{week}$ 주중 총 중강도 활동은 2262.59METs/week이었으며 주중 총 고강도 시간은 $122.95 \mathrm{~min} /$ week, 총 고강도 활동은 995.67METs/week로 나타났다.

뉴질랜드 훈련의 경우 측정 기간 중 대회 일정과 기상 악화로 인해 월, 토요일만 정상적으로 계획된 훈련을 소화하고 대회의 전후인 화, 금요일은 휴식을 위주로 주간 일정이 진행되어 화·금·일요일의 'Sedentary'와 'Light' 활동의 비율이 매우 높았다.

뉴질랜드 훈련기간 에너지소비량 차이

뉴질랜드 전지훈련의 일별 에너지소비량은 〈Table 15〉와 같다. 일일
총 에너지소비량은 대회 이후 금요일이 $2089.32 \pm 269.42 \mathrm{Kcal}$ 로 가장 낮았고, 대회 1 일차 수요일이 $2674.07 \pm 164.84 \mathrm{kcal}$ 로 가장 높게 나타났다. 스키훈련 시 에너지소비량은 회전 게이트 훈련을 실시한 월요일이 $680.30 \pm 29.08 \mathrm{kcal}$ 로 가장 높았으며, 기상악화로 인해

Table 15. Daily energy expenditure (New Zealand group)

(kcal)

\begin{tabular}{ccccccc}
\hline & \multicolumn{6}{c}{ Energy expenditure } \\
\cline { 2 - 7 } & \multicolumn{2}{c}{ Daily total } & \multicolumn{2}{c}{ Ski training } & \multicolumn{2}{c}{ Fitness training } \\
\cline { 2 - 7 } & $M$ & $S D$ & $M$ & $S D$ & $M$ & $S D$ \\
\hline Mon & 2666.88 & 318.28 & 680.30 & 29.08 & 450.01 & 199.16 \\
\hline Tue & 2291.53 & 242.07 & 336.45 & 33.55 & 468.65 & 172.93 \\
\hline Wed & 2674.07 & 164.84 & 530.36 & 103.13 & 558.95 & 40.16 \\
\hline Thu & 2469.34 & 172.62 & 531.04 & 66.54 & 365.46 & 56.51 \\
\hline Fri & 2089.31 & 269.42 & 307.58 & 26.39 & 362.49 & 26.58 \\
\hline Sat & 2592.19 & 193.39 & 640.47 & 39.89 & 446.06 & 68.02 \\
\hline Sun & 2093.94 & 154.28 & 346.75 & 14.37 & 312.34 & 24.11 \\
\hline
\end{tabular}

Table 14. Mean daily time spent on different activity intensity (New Zealand group)

\begin{tabular}{|c|c|c|c|c|c|c|c|c|c|c|c|c|c|c|}
\hline & \multicolumn{2}{|c|}{ Mon } & \multicolumn{2}{|l|}{ Tue } & \multicolumn{2}{|l|}{ Wed } & \multicolumn{2}{|l|}{ Thu } & \multicolumn{2}{|l|}{ Fri } & \multicolumn{2}{|l|}{ Sat } & \multicolumn{2}{|l|}{ Sun } \\
\hline & $M \pm S D$ & $\%$ & $M \pm S D$ & $\%$ & $M \pm S D$ & $\%$ & $M \pm S D$ & $\%$ & $M \pm S D$ & $\%$ & $M \pm S D$ & $\%$ & $M \pm S D$ & $\%$ \\
\hline $\begin{array}{l}\text { Sleep and } \\
\text { sedentary }\end{array}$ & $\begin{array}{r}829.00 \\
\pm 62.92 \\
\end{array}$ & 57.6 & $\begin{array}{r}1069.80 \\
\pm 100.73 \\
\end{array}$ & 74.3 & $\begin{array}{c}915.8 \\
\pm 170.24\end{array}$ & 63.6 & $\begin{array}{c}833.6 \\
\pm 172.23 \\
\end{array}$ & 57.9 & $\begin{array}{c}1050.6 \\
\pm 70.50 \\
\end{array}$ & 73.0 & $\begin{array}{c}880.4 \\
\pm 76.43 \\
\end{array}$ & 61.1 & $\begin{array}{c}1057.4 \\
\pm 128.65 \\
\end{array}$ & 73.4 \\
\hline Light & $\begin{array}{r}463.80 \\
\pm 41.37 \\
\end{array}$ & 32.2 & $\begin{array}{c}283.80 \\
\pm 88.16\end{array}$ & 19.7 & $\begin{array}{c}399 \\
+146.10\end{array}$ & 27.7 & $\begin{array}{c}498.4 \\
\pm 138.60 \\
\end{array}$ & 34.6 & $\begin{array}{c}339.4 \\
\pm 68.29 \\
\end{array}$ & 23.6 & $\begin{array}{c}416.8 \\
+75.97 \\
\end{array}$ & 28.9 & $\begin{array}{c}329.4 \\
\pm 114.31 \\
\end{array}$ & 22.9 \\
\hline Moderate & $\begin{array}{r}130.40 \\
\pm 39.95 \\
\end{array}$ & 9.1 & $\begin{array}{c}67.80 \\
\pm 31.17 \\
\end{array}$ & 4.7 & $\begin{array}{c}77 \\
\pm 35.01 \\
\end{array}$ & 5.3 & $\begin{array}{c}99.4 \\
+35.98 \\
\end{array}$ & 6.9 & $\begin{array}{c}49 \\
\pm 15.08 \\
\end{array}$ & 3.4 & $\begin{array}{c}124.8 \\
\pm 20.44 \\
\end{array}$ & 8.7 & $\begin{array}{c}47.6 \\
+16.29 \\
\end{array}$ & 3.3 \\
\hline Vigorous & $\begin{array}{r}16.80 \\
\pm 2.77 \\
\end{array}$ & 1.2 & $\begin{array}{c}23.25 \\
\pm 11.59\end{array}$ & 1.6 & $\begin{array}{c}48.2 \\
\pm 6.06 \\
\end{array}$ & 3.3 & $\begin{array}{c}8.6 \\
\pm 3.13 \\
\end{array}$ & 0.6 & $\begin{array}{c}2.5 \\
\pm 2.12 \\
\end{array}$ & 0.2 & $\begin{array}{c}18 \\
+7.62 \\
\end{array}$ & 1.3 & $\begin{array}{c}5.6 \\
\pm 1.34 \\
\end{array}$ & 0.4 \\
\hline \multicolumn{5}{|c|}{ Weekly total Moderate time (min/week) } & 596.00 & & \multicolumn{6}{|c|}{ Weekly total Moderate METs (METs/week) } & \multicolumn{2}{|l|}{2262.59} \\
\hline \multicolumn{5}{|c|}{ Weekly total Vigorous time (min/week) } & 122.95 & & \multicolumn{6}{|c|}{ Weekly total Vigorous METs (METs/week) } & \multicolumn{2}{|l|}{995.67} \\
\hline
\end{tabular}

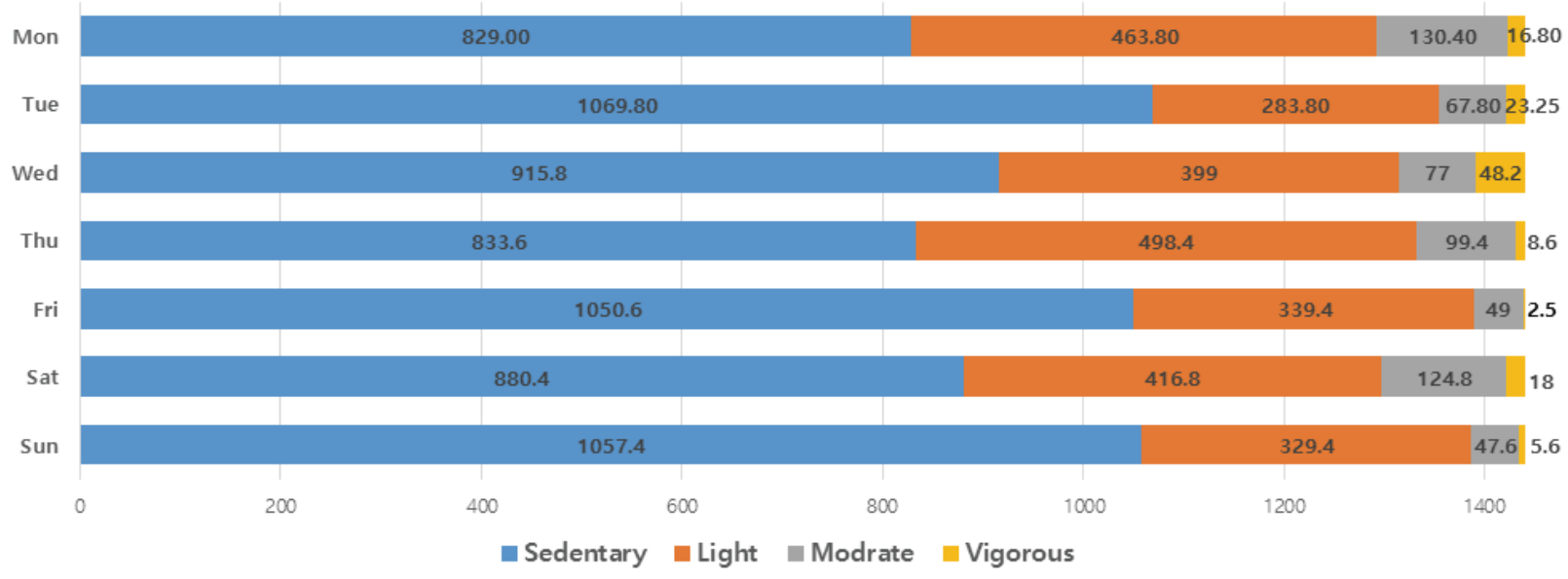

Fig. 4. Mean daily time spent on different activity intensity (New Zealand group) (min) 
Table 16. Difference of energy expenditure (New Zealand group) (kcal)

\begin{tabular}{|c|c|c|c|c|c|}
\hline & $M$ & $S D$ & $t$ & $d f$ & $p$ \\
\hline Weekday total & 2438.23 & 169.05 & \multirow{2}{*}{4.033} & \multirow{2}{*}{5} & \multirow{2}{*}{.016} \\
\hline Weekend total & 2343.07 & 162.20 & & & \\
\hline $\begin{array}{c}\text { Weekday } \\
\text { ski training }\end{array}$ & 477.15 & 26.66 & \multirow{2}{*}{-1.351} & \multirow{2}{*}{5} & \multirow{2}{*}{.248} \\
\hline $\begin{array}{c}\text { Weekend } \\
\text { fitness training }\end{array}$ & 493.61 & 23.38 & & & \\
\hline $\begin{array}{c}\text { Weekday } \\
\text { ski training }\end{array}$ & 441.11 & 46.82 & \multirow{2}{*}{2.632} & \multirow{2}{*}{5} & \multirow{2}{*}{.058} \\
\hline $\begin{array}{c}\text { Weekend } \\
\text { fitness training }\end{array}$ & 379.20 & 33.86 & & & \\
\hline Ski training & 481.85 & 22.63 & \multirow{2}{*}{2.546} & \multirow{2}{*}{4} & \multirow{2}{*}{.064} \\
\hline Fitness training & 423.42 & 36.44 & & & \\
\hline
\end{tabular}

프리스키를 실시한 일요일이 $346.75 \pm 14.37 \mathrm{kcal}$ 로 가장 낮았다. 체력훈련 에너지소비량은 수요일이 $558.95 \pm 40.16 \mathrm{kcal}$ 로 가장 높은 것으로 나타났으며 일요일이 $312.34 \pm 24.11 \mathrm{kcal}$ 로 가장 낮았다.

뉴질랜드 전지훈련의 주중과 주말, 스키훈련과 체력훈련 에너지 소비량 차이를 분석한 결과는 〈Table 16)과 같다. 주중, 주말의 총 에너지소비량의 경우 주중 평균 $2438.23 \pm 169.05 \mathrm{kcal}$ 이었으며, 주말은 평균 $2343.07 \pm 162.20 \mathrm{kcal}, p=.016$ 으로 통계적으로 유의한 차이가 있었다. 훈련별 차이를 살펴보면 주중 스키 훈련 에너지소비량의 경우 평균 $477.15 \pm 26.66 \mathrm{kcal}$, 주말 스키 훈련은 평균 $493.61 \pm 23.38 \mathrm{kcal}, p=.248$ 로 나타나 주중, 주말 스키훈련은 차이가 없었으며, 체력훈련의 에너지소비량은 주중 평균 $441.11 \pm 46.82 \mathrm{kcal}$, 주말 $379.20 \pm 33.86 \mathrm{kcal}, p=.058$ 로 통계적으로 유의한 차이는 없었다. 훈련구분에 따른 에너지소비량 차이 분석결과 스키훈련 시 에너지소비량 평균 $481.85 \pm 22.63 \mathrm{kcal}$ 이었으며, 체력훈련의 에너지소비량은 평균 $423.42 \pm 36.44 \mathrm{kcal} p=.064$ 로 훈련구분에 따른 에너지소비량은 차이가 없는 것으로 나타났다.

\section{논의}

본 연구의 목적은 삼축가속도계를 이용한 알파인 스키 전지훈련의 모니터링을 통해 훈련 기간 동안의 다양한 활동 특성을 분석하여 체계적인 훈련계획을 위한 기초자료를 마련하고, 이를 통해 정량적 자료를 기반으로 훈련을 평가하는 방법을 제안하는데 있다. 이를 위하 삼축가속도계 Actigraph GT9X를 이용하여 프랑스와 뉴질랜드에서 이루어진 우리나라 알파인 스키 선수들의 주간 훈련 자료를 수집하고 분석하였다.

\section{활동 강도 패턴과 에너지소비량}

활동 강도 변화의 경우 프랑스와 뉴질랜드 모두 계획된 스키훈련 및 대회 시간 동안 고강도의 활동이 짧은 시간동안 나타났다가 사라지는 형태가 반복적으로 이루어지고 있었다. 이는 경기시간이 60초에서 최대 120 분 정도이며 선수들 간 기록 차이가 $1 / 100$ 초로 매우 짧은
시간적 특성(Dzimbova et al., 2020; Ferguson, 2010)을 가지는 알파인 스키의 종목 특성에 따른 것으로 Polat(2016)는 대회전(GS) 선수들에 대한 운동 강도 분석에서 대회전 스키 중 선수들의 심박수는 최고 $201.7 \pm 2 \mathrm{bpm}$, 평균 $168.8 \pm 1.82 \mathrm{bpm}$ 으로 나타나며 이러한 심박수 변화는 슬로프를 내려가는 순간부터 급격히 증가하였다가 코스가 끝날 무렵 최대 수준에 도달하는 것으로 보고하였다. 본 연구의 활동 강도 변화 역시 이와 유사했으며 이것은 스키를 타는 짧은 순간에 활강과 속도 제어, 회전을 위해 선수들은 자신이 낼 수 있는 최대의 능력을 발휘하는 집중운동을 하고 있는 것으로 해석 할 수 있고, 훈련 및 대회과정에서 이러한 높은 강도의 활동에 지속적이고 반복적으로 노출 되고 있는 것으로 볼 수 있다. 이러한 강도는 높고 지속시간이 짧은 형태의 스키 활동 강도 형태는 프리스키, 숏폴, 회전, 대회전 훈련 모두 유사한 강도 변화를 보이는 것으로 나타났으며 대회기간 동안에도 활동 강도 패턴은 훈련과 비슷하게 나타났다.

스키훈련에 따른 에너지소비량은 4 시간 내외로 비교적 장시간 실시되는 훈련시간에 비해 예상보다 다소 낮게 나타났는데 이는 훈련 강도가 높다고 하더라도 지속시간이 짧으면 에너지소비량은 낮을 수 있음을 의미하는 것으로 볼 수 있다. 에너지소비량 차이 분석결과 프랑스의 경우 주중과 주말의 에너지소비량에 차이가 있었는데 이는 측정기간 중 실시된 주중, 주말 훈련 내용에 따른 차이인 것으로 각기 다른 훈련 계획과 운영은 선수들의 활동 강도에도 영향을 미치며 그로인한 에너지소비량 역시 진행되는 훈련의 내용과 강도에 따라 차이가 나타나는 것으로 볼 수 있다(Frączek, et al, 2019). 체력훈련은 당일 훈련 내용과 선수 개별 특성에 따라 다소 차이가 있기는 했으나 프랑스와 뉴질랜드 모두 스키훈련 강도가 높을 경우 체력은 상대적으로 낮은 강도로 진행되고 있는 형태를 보였다. 이는 에너지소비량 분석결과에서도 나타났는데 스키훈련으로 인한 주말 에너지소비량이 주중보다 높았던 프랑스의 경우 오히려 체력훈련으로 인한 에너지소비량은 주중 보다 낮게 낮은 것으로 분석되었으며 통계적으로 유의한 차이는 없었지만 뉴질랜드 역시 체력훈련으로 인한 에너지소비량은 스키훈련 보다 다소 낮은 경향을 보였다.

스키와 체력훈련의 활동 강도와 그에 따른 에너지소비량을 종합적으로 살펴보았을 때 알파인 스키선수들의 훈련은 주중과 주말 구분 없이 진행되며 대신 훈련일정에 따라 주중에 휴식을 취하는 형태를 가지고 있었다. 이로 인해 훈련내용에 따라 다소 차이가 있었지만 주말과 주중에 유사한 활동 강도 변화가 나타났다. 이는 동계종목이라는 알파인 스키의 종목 특성에 의해 전지훈련이 1 2개월로 비교적 짧게 계획되어 주중, 주말의 구분 없이 훈련하기 때문인 것으로 이때 지도자는 스키와 체력, 오전과 오후 훈련의 강도를 적절한 비율로 조정하여 훈련을 계획하고 실행하고 있는 것으로 보여진다.

운동선수를 위한 훈련 계획에서는 향상 시키고자 하는 신체와 기술적 요인에 따라 훈련 목표와 강도가 달라질 수 있다. 이로 인해 훈련을 통해 나타나는 선수의 일일 에너지소비는 당일의 훈련 내용과 강도에 따라 변화 될 수 있으며, 동일한 훈련에 참가했다 하더라도 훈련시간을 제외한 일상생활 방식에 따라서도 요일별로 다르게 나타날 수 있다(Frączek, et al, 2019). 따라서 효과적인 훈련을 위해 훈련과 일상생활의 활동 강도와 그에 따른 에너지소비, 휴식 등을 균형 있게 조절하여 주중과 주말의 훈련 계획을 수립하고 운영할 수 있는 지도자의 전문적 역량이 필요(Schlechter et al., 2017; Woods, et al.,2017)할 것으로 사료된다. 


\section{주간 강도별 활동시간}

활동 강도에 따른 일일 시간 분류 및 특징을 분석한 결과 수면시간을 포함한 'Sedentary' 비율이 가장 높았고 다음으로 'Light(저강도)', 'Moderate(중강도)', 'Vigorous(고강도)'의 순서로 나타났다. 일반적인 성인의 경우 일상생활에서 하루기준 수면 $31 \%$, 'Sedentary' $39 \%$, 'Light' 27\%, 'Moderate' 2.5\%, 'Vigorous' 이상 0.5\% 비율의 신체활동 강도별 시간을 나타낸다(Norton, Norton \& Sadgrove, 2010). 이에 비해 스키선수들이 계획된 스키 훈련을 실시하는 경우 수면 시간과 'Sedentary' 비율은 54.9 67.3\% 수준으로 'Light'의 경우 25.5 34.9\%로 나타났고 이에 비해 중강도 이상의 활동인 'Moderate'와 'Vigorous'이상 활동은 각각 $5.8 \sim 9.8 \%, 1.1 \sim 2.2 \%$ 로 나타나 일반인들 보다 고강도 활동이 하루 중에 차지하는 비율이 높았다. 또한 프랑스 전지훈련의 주중 총 중강도 활동 시간은 $836.67 \mathrm{~min} / \mathrm{week}$, 총 중강도 활동은 $3259.72 \mathrm{METs} / \mathrm{week}$ 이었으며 주중 총 고강도 시간은 $135.17 \mathrm{~min} / \mathrm{week}$, 총 고강도 활동은 $1092.05 \mathrm{METS} / \mathrm{week}$ 으로 나타났다. 뉴질랜드는 훈련의 총 중강도 활동 시간은 $596 \mathrm{~min} / \mathrm{week}$, 총 중강도 활동은 $2262.59 \mathrm{METs} / \mathrm{week}$ 이었으며 주중 총 고강도 시간은 $122.95 \mathrm{~min} / \mathrm{week}$, 총 고강도 활동은 995.67METs/week으로 나타났다. 이는 건강과 체력의 유지 및 증진을 위해 권장되고 있는 우리나라의 신체활동 기준(중강도 활동: 주당 $150 \mathrm{~min} / \mathrm{week}$ 또는 600METs/week, 고강도 활동 강도: $75 \mathrm{~min} /$ week 또는 $600 \mathrm{METs} / \mathrm{week}$ ) (Korea Health Promotion Institution, 2012)과 American College of Sports Medicine(ACSM)의 권장기준(중등도 유산소 신체 활동: 주당 5일 동안 최소 30 분, 고강도 유산소 활동: 주당 3 일 동안 최소 20 분 동안, 근력운동: 주 2회 이상)(ACSM, 2017)과 비교하였을 때 매우 높은 것으로 운동선수라는 대상의 특이성을 고려하더라도 높은 수준의 활동이 훈련 기간 동안 장기간 이어지고 있는 것으로 볼 수 있다.

운동선수의 체계적이고 효과적인 훈련을 위해 종목의 특성과 훈련시기(예: 비시즌/시즌/시합기)에 따라 체력과 기술을 향상시키기 위한 훈련의 목표와 내용을 고려하여 적절한 비율의 강도별 훈련을 구성하며 이때 휴식을 포함하는 신체적 과부하 기간이 포함하여야 한다(Schelchter, et al.,2018). 이는 생리적 적응과 충분한 회복의 반복을 통해 체력과 수행 능력을 향상시키기 위한 것으로 장기간의 훈련 기간을 주기 별로 설정하는 것이 일반적이다. 하지만 지나친 고강도 훈련으로 인한 과부하는 심리적·신체적 피로의 누적으로 인해 오히려 기대 이하의 수행능력이 발휘 되거나 부상의 원인 등 악영향을 미칠 수 있다(Woods, et al.,2017). 또한 전지훈련기간이 짧아 주중과 주말의 구분 없이 훈련이 이루어지고 있는 알파인 스키선수들은 낮은 온도와 높은 고도의 환경에서 장시간 반복적으로 훈련을 실시하고 있다. 이때 축적되는 젖산량은 저산소 조건으로 인해 추가로 증가될 수 있어 저온, 저압, 저산소의 환경적 조건에서는 선수들의 회복이 원활하게 이루어지지 않을 수 있다(Polat, 2016). 그리고 연구자료 수집기간 중 악천후로 인해 훈련과 대회가 취소되는 경우가 있었는데 이런 경우 계획된 훈련 내용과 강도를 유지하며 규칙적인 훈련을 운영하는 것과 선수들의 컨디션 조절 등에 어려움을 줄 수 있어 훈련의 효과를 떨어뜨리는 원인으로 작용할 것으로 생각된다. 따라서 경기력 향상을 위한 효과적인 훈련계획을 위해서는 신체적·기술적 요인과 더불어 환경과 날씨에 따른 컨디션 조절 및 적절한 휴식과 피로회복까지 종합적으로 고려(Dzimbova et al., 2020; Koller \& Schobersberge, 2019; Neumayr, et al., 2003; Nilsson et al.,
2018)하여 훈련의 효율성을 높이기 위한 다양한 노력이 필요할 것으로 보여진다.

\section{가속도계 기반의 훈련 모니터링}

스키는 환경, 장비, 선수의 심리, 신체적 요인들이 종합적으로 작용하는 복잡한 종목으로 다양한 변인이 경기력에 영향을 미친다(Polat, 2016). 이에 알파인 스키선수들은 훈련주기와 계절에 따라 비시즌 체력훈련/시즌 기술훈련 등으로 훈련이 목적과 내용이 달라지며(Neumayr, et al., 2003) 전지훈련과 시합으로 인해 훈련 지역 역시 변화하게 된다. 따라서 효과적인 경기력 향상을 위한 전략으로 훈련 주기에 따라 체계화 된 훈련 모형을 구성하고 이에 따른 훈련을 진행할 필요성이 있다. 이에 미국, 캐나다 같은 스키 선진국은 올림픽 설상 종목에 대해 세부 종목별로 연령, 훈련 시기에 따른 훈련을 여러 개의 기능적 구성요소들을 조합함으로써 계획 및 실행할 수 있도록 모듈(module)화 된 훈련 프로그램을 개발하여 보급하고 있다(Alpine Canada, 2021; Freestyle Canada, 2021; US ski team 2021). 이러한 프로그램은 스키 세부 종목별로 시즌기와 비시즌기로 구분하여 기초부터 시합준비를 위한 기술훈련 뿐 아니라 성별과 연령, 경기력 수준을 고려한 체력훈련 내용을 기본으로 적절한 훈련 환경과 조건 선택을 위한 권장 사항도 포함되어 있다. 또한 적절한 에너지 공급 및 회복을 위한 영양섭취와 수면 형태 관리 방안, 훈련 및 시합을 위한 심리적 관리방안과 일상생활 양식까지 함께 제시하고 있다(Alpine Canada, 2021; Freestyle Canada, 2021; US ski team 2021).

우리나라 역시 알파인 스키선수들의 경기력 향상을 위해 체계적이고 상세하게 구성된 훈련 프로그램을 개발하고 보급할 필요성이 있다. 이러한 훈련 프로그램 구성을 위해 체력뿐 아니라 현재 운영 중인 스키 및 체력 훈련 요소에 대한 각각의 정량적 측정이 우선(Alejo et al., 2021; Stöggle, et al., 2016)되어야 하지만 스키의 경우 측정 장비를 착용한 상태에서 활동의 제약을 많이 받기 때문에 상대적으로 크기가 작아 착용 시 신체 및 활동에 부담이 적은 가속도계는 훈련 내용에 따른 정량적 자료수집의 효과적인 방법으로 판단된다.

훈련 시간·빈도·강도·에너지소비 등의 훈련량에 대한 기준을 마련하기 위해 스키와 체력 훈련 내용을 세분화 하고 가속도계 기반의 측정 장비를 착용한 상태에서 각각의 훈련을 실시하여 훈련 내용과 시간에 따른 활동 강도 및 에너지소비량을 측정한 뒤 결과를 분류 및 정리하는 표준화 작업을 하여 이 결과를 지도자들이 현장에서 활용한다면 훈련 주기에 따라 필요한 적절한 강도의 내용으로 훈련을 구성하고 실시(Alejo et al., 2021; Neville, et al., 2010; Schlechter, et al., 2018)할 수 있을 것이다. 그리고 가속도계의 축(X, Y, Z)별 정보를 통해 운동 특성(Lukàšek et al., 2016)을 파악해 보다 효과적인 운동처방과 부상예방을 운동방법 선정을 위한 기초자료로 활용할 수 있을 것으로 생각된다. 이와 더불어 무선 심박수계나 GPS 등의 기기와 연동도 가능(Actigraph, 2021a)한 가속도계기반 장비의 장점을 충분히 활용한다면 다양한 변인의 단기간, 장기간 정량적인 훈련 자료 수집을 위한 현장 검사도구로서의 활용가능성 뿐 아니라 스키 선수들의 경기력 향상을 위한 연구영역의 확장에도 충분히 그 역할을 할 수 있을 것으로 보여진다.

또한 최근 문제가 되고 있는 코로나 19로 인한 비대면 또는 격리 기간 중 훈련을 실시해야 하는 경우 삼축가속도계나 이를 기반으로 한 
웨어러블(wearable) 신체활동 측정기기를 활용하면 선수와 지도자가 별도의 공간, 국가에 있어도 효과적인 훈련 모니터링이 가능할 것으로 보여지며, 이때 선수를 지도자가 감시하는 것이 아닌 보다 객관적인 결과를 기반으로 함께 훈련을 운영하고 정리하는 형태의 모니터링이 이루어진다면 훈련이 종료 된 이후 측정된 누적자료의 분석을 통해 현재의 훈련 평가 뿐 아니라 다음 훈련을 위한 정량적이고 객관적인 기준을 제시할 수 있을 것으로 사료된다.

\section{결론 및 제언}

본 연구는 삼축가속도계를 활용한 전지훈련 기간 중 나타나는 알파인 스키선수들의 활동특성을 분석하여 효과적인 훈련을 계획하기 위한 정량적 기초자료를 제공하는데 그 목적이 있다.

연구결과 활동 강도 변화와 에너지소비량의 경우 주말, 주중 훈련 내용에 따라 변화하였다. 스키훈련 및 대회 시간 동안에는 고강도의 활동이 짧은 시간동안 나타났다가 사라지는 형태가 반복적으로 나타났으며 당일 스키 훈련 강도가 높을 경우 체력 훈련은 상대적으로 낮은 강도로 실시되고 있었다. 또한 이러한 활동형태는 주말과 주중의 구분 없이 유사한 형태를 보였다. 활동 강도에 따른 시간 분류 및 특징은 주중 총 중강도 및 고강도 활동 시간이 매우 높게 나타났다. 따라서 이러한 활동 특성을 고려하여 적절한 휴식 및 운동 강도를 유지할 수 있는 알파인 스키선수들을 위한 체계적인 훈련 프로그램을 개발할 필요성이 있을 것으로 사료된다.

본 연구는 삼축가속도계를 활용한 알파인 스키선수들의 훈련 모니터링의 가능성을 확인하는 기초연구로 활동 강도와 그에 따른 에너지소비량에 초점을 맞춘 분석을 실시하였다. 후속연구에서는 수면패턴이나 GPS, 무선심박수계 등의 추가적인 기능을 활용하여 보다 장기간 모니터링을 진행한다면 현장에 보다 다양한 정보를 제공할 수 있을 것으로 생각된다. 또한 본 연구에서는 훈련지 및 훈련에 참가한 대상자가 동일하지 못한 제한점이 있어 후속 연구에서는 동일한 대상자의 훈련지별 자료 수집을 통해 훈련 내용 뿐 아니라 훈련지역에 따라 나타나는 다양한 차이에 대한 분석에 대한 후속연구가 필요할 것으로 생각된다. 


\section{참고문헌}

Actigraph. (2021a). https://actigraphcorp.com/actigraph-link/

Actigraph. (2021b). https://actigraphcorp.my.site.com/support/s/ article/What-is-the-difference-among-the-Energy-ExpenditureAlgorithms

Actigraph. (2021c). https://actigraphcorp.my.site.com/support/s/ article/What-s-the-difference-among-the-Cut-Points-available-inActiLife

Actigraph. (2021d). https://actigraphcorp.my.site.com/support/s/ article/What-is-the-difference-among-the-MET-Algorithms

Alejo, L. B., Gil-Cabrera, J., Montalvo-Perez, A., Barranco, D., Hortal-Fóndon, J., \& Navandar, A. (2021). Performance Parameters in Competitive Alpine Skiing Disciplines of Slalom, Giant Slalom and Super-Giant Slalom. International Journal of Environmental Research and Public Health, 18(5), 2628.

Alpine Canada. (2021). https://tad.alpinecanada.org/athletes/physicalfitness

American College of Sports Medicine. (2017). Benefits and Risks Associated with Physical Activity. ACSM's Guidelines for Exercise Testing and Prescription(10th ed., pp. 1-21). Philadelphia: Wolters Kluwer.

Crouter, S. E., Churilla, J. R., \& Bassett Jr., D. R. (2006). Estimating energy expenditure using accelerometers. European Journal of Applied Physiology, 98(6), 601-612.

Dzimbva, T. A. \& Kirkova, M. (2020). Impact of training and competitions in alpine skiing on the anaerobic capacity of adolescent athletes. Journal of Physical Education and Sport, 20(5), 2628-2636

Fédération Internationale de Ski. (2021a). The International Ski Competition Rules. (July 2021 ed.) https://assets.fis-ski.com/ image/upload/v1627946604/fis-prod/assets/ICR_02082021.pdf

Fédération Internationale de Ski. (2021b). https://www.fis-ski.com/ DB/alpine-skiing/calendar-results.html?noselection=true

Ferguson, R. A. (2010). Limitations to performance during alpine skiing. Experimental Physiology, 95(3), 404-410.

Frączek, B. Grzelak, A. \& Klimek, A. T. (2019). Analysis of Daily Energy Expenditure of Elite Athletes in Relation to their Sport, the Measurement Method and Energy Requirement Norms. Journal of Human Kinetics, 70, 81-92.

Freestyle Canada. (2021). https://freestylecanada.ski/a/en/resources/ hpad/index.html

Harris, J. A. \& Benedict, F. G. (1918). A Biometric Study of Human Basal Metabolism. Proceeding of the National Academy of Science of the United States of America, 4(12), 370-373.

Jagim, A. R., Camic, C. L., Kisiolek, J., Luedke, J., Erickson, J., Jones, M. T., \& Oliver, J. M. (2018). Accuracy of Resting Metabolic Rate Prediction Equations in Athletes. Journal of Strength and Conditioning Research, 32(7), 1875-1881.

Koller, A., \& Schobersberge, W. (2019). Preseason aerobic and anaerobic tests for prediction of alpine skiing performance: a molecular perspective. BMJ Open Sport \& Exercise Medicine 5(1), e000510.

Korea Health Promotion Institute. (2012). Development of physical activity guidelines and self-prescribed guidelines for Koreans. Health Promotion Research Project, 12-37, Seoul: Korea Health Promotion Institute.

Korea Ski Association. (2021). https://ski.sports.or.kr/Common_ SkiKind/content2_1_1.jsp

Leek, D., Carlson, J. A., Cain, K. L., Henrichon. S., Rosenberg, D., Patrick, K., \& Sallis, J. F. (2011). Physical Activity During Youth Sports Practices. Arch Pediatr Adolesc Med, 165(4), 294299.

Leinonen, A. M., Ahola, R., Kulmala J., Hakonen, H., Vähä-Ypyä, H., Herzig, K-H., ... Jämsä, T. (2017). Measuring Physical Activity in Free-Living Conditions-Comparison of Three Accelerometry-Based Methods. Frontiers in Physiology, 7, Article 681.

Lukàšek, M. \& Vychodilovà, R. (2016). Accelerometry in sport. Journal of Human Sport and Exercise, 11(1), S125-S136.

Mcnally, K. (2017). Comparing MVPA, Energy Expenditure, RPE, and Enjoyment of a U12 Boys Soccer team during a non-competition ("friendly") game vs. a competition ("league") game. Paper presented at Exercise Science, 2017 Sacred Heart University Academic Festival.

Neumayr, G., Hoertnagl, H., Pfister, R., Koller, A., Eibl, G., \& Raas, E. (2003). Physical and physiological factors associated with success in professional alpine skiing. Int J Sports Med, 24(8), 571-575.

Neville, J., Wixeted, A., Rowlands, D., \& James, D. (2010). Accelerometers: An underutilized resource in sports monitoring. 2010 Sixth International Conference on Intelligent Sensors, Sensor Networks and Information Processing, 287-290.

Nilsson, R., Lindberg, A., Theos, A., Ferguson, R. A., \& Malm, C. (2018). Aerobic Variables for Prediction of Alpine Skiing Performance - A Novel Approach. Sports Medicine International Open, 2(4), E105-E112.

Norton, K., Norton, L., \& Sadgrove, D. (2010). Position statement on physical activity and exercise intensity terminology. Journal of Science and Medicine in Sport, 13(5), 496-502.

Polat, M. (2016). An examination of respiratory and metabolic demands of alpine skiing. Journal of Exercise Science and Fitness, 14(2), 76-81.

Santos-Lozano, A., Santín-Medeiros, F., Cardon, G., TorresLuque, G., Balión, R., Bergmeir, C., ... Garatachea, N. (2013). Actigraph GT3X : Validation and Determination of Physical Activity Intensity Cut Points. International Journal of Sports Medicine, 34(11), 975-982.

Schlechter, C. R., Guagliano, J. M., Rosenkranz, R. R., Milliken, G. A., \& Dzewaltowski, D. A. (2018). Physical activity patterns across time-segmented youth sport flag football practice. $B M C$ Public Health, 18, 226. 
Schlechter, C. R., Rosenkranz, R. R., Milliken, G. A., \& Dzewaltowski, D. A. (2017). Physical activity levels during youth sport practice: does coach training or experience have an influence?. Journal of Sports Sciences, 35(1), 22-28.

Shiroma, E. J., Schepps, M. A., Harezlak, J. T., Chen, K. Y., Matthews, C. E., Koster, A., ... Harris, T. B. (2016). Daily physical activity patterns from hip- and wrist-worn accelerometers. Physiol Meas, 37(10), 1852-1861.

Silva, A. M., Matias, C. N., Santos, D. A., Thomas, D., BosyWestphal, A., Müller., M. J., \& Sardinha, L. B. (2017). Energy Balance over One Athletic Season. Medicine \& Science in Sports \& Exercise, 49(8), 1742-1733.

Stöggl, T., Schwarzl, C., Müller, E. E., Nagasaki, M., Stöggl, J., Scheiber, P., ... Niebauer, J. (2016). A Comparison between Alpine Skiing, Cross-Country Skiing and Indoor Cycling on Cardiorespiratory and Metabolic Response. Journal of Sports Science and Medicine 15(1), 184-195.

Troiano, R. P., McClain, J. J., Brychta, R. J., \& Chen, K. Y. (2014). Evolution of accelerometer methods for physical activity research. British Journal of Sports Medicine, 48(13), 1019-1023.

US ski team. (2021). http://usskiandsnowboard.org/sport-programs/ training-systems

Woods, A. L., Garvican-Lewis, L. A., Lundy, B., Rice, A. J., \& Thompson, K. G. (2017). New approaches to determine fatigue in elite athletes during intensified training: Resting metabolic rate and pacing profile. PLOS ONE, 12(3), e0173807. 


\section{삼축가속도계를 활용한 알파인 스키 선수의 전지훈련 모니터링}

석진수 ${ }^{1}$, 강성기 ${ }^{1}$, 이재형 ${ }^{1}$, 지영하 ${ }^{2}$

1 용인대학교

${ }^{2}$ 대한스키협회

[목적] 삼축가속도계를 이용한 알파인 스키 전지훈련 모니터링을 통해 정량적 자료를 기반의 훈련 평가 방법을 제안하고자 한다.

[방법] 프랑스(남자 4 명, 여자 2 명)와 뉴질랜드(남자 4 명, 여자 2 명)의 전지훈련에 참가한 총 12 명의 우리나라 알파인스키 선수를 대상으로 전지훈련 동안 Actigraph GT9X를 착용하여 훈련, 일상생활동안의 활동정보를 수집하였으며 총 7일의 자료를 활용하였다. 수집 된 자료는 ActiLife Ver 6.13.1를 통해 다운로드 받아 Freedson(2011)으로 에너지소비량을 산 출하고 Harris \& Benedict(1918)공식을 통한 휴식대사량으로 보정하였으며, Freedson(1998) 신체활동 강도 분류기준 과 Freedson(1998) METs공식을 이용하여 시간별 활동 강도를 구분하였다. 자료처리는 Window Excel 2016로 날짜, 시간, 강도, 에너지소비량에 따라 정리하고 Windows SPSS 23을 사용한 종속표본 t-test를 통해 주중과 주말, 훈련내용 에 따른 차이를 분석했으며 유의수준은 $\mathrm{a}=.05$ 로 설정하였다.

[결과] 첫째, 프랑스와 뉴질랜드 모두 계획된 스키훈련 및 대회 시간 동안 고강도의 활동이 짧은 시간동안 나타났다가 사 라지는 형태가 반복적으로 이루어지고 있었다. 둘째, 중강도 이상 활동은 훈련 내용에 따라 일별로 다소 차이가 있었지만 6 10\% 내외의 비율을 차지하고 있었으며 주당 총 중강도 이상 활동 시간과 강도가 매우 높았다. 셋째, 훈련내용에 따라 프랑스 주중·주말의 총 에너지소비량(p〈.05), 주중·주말 스키훈련(p〈.05)과 체력훈련(p〈.05)의 에너지소비량에 차이가 있었고, 뉴질랜드는 주중·주말의 총 에너지소비량에서 차이가 나타났다(p<.05).

[결론] 정량적 측정을 통한 훈련평가 결과를 활용하여 적절한 휴식 및 운동 강도를 유지할 수 있는 알파인 스키선수들을 위한 체계적인 훈련 프로그램을 개발할 필요성이 있을 것으로 사료된다.

주요어

알파인 스키, 삼축가속도계, 훈련 모니터링 